\title{
Aravalli Craton and its Mobile Belts: An Update
}

\author{
*Geological Survey of India, Bangalore; Email: fareedromani@gmail.com \\ **Department of Geology, University of Delhi, Delhi- 110007; Email: dhirajmohanbanerjee@gmail.com; \#Corresponding Author
}

(Received : 05/05/2019; Revised accepted : 17/09/2019)

https://doi.org/10.18814/epiiugs/2020/020005

The continued existence of an Eo-Paleoarchean proto-continent through Proterozoic times in the Aravalli Mountain Range is now widely accepted. The protocontinent's growth culminated with the outpouring of 2.5 Ga old silicic magma by the end of Neoarchean, which produced polyphase granites-gneisses, and migmatites of the 'Banded Gneissic Complex.' The polycyclic Proterozoic orogenic processes involved crustal thickening and thermal perturbations, which reconstituted its pristine character. The term Banded Gneissic Complex (BGC) as a valid lithodemic unit has survived while nomenclature like Mangalwar Gneiss and Mewar Gneiss failed to satisfy the international stratigraphic code. BGC with relics of ancient supracrustals and komatiitic bodies display a wide range of relationship with the cover rocks. Its subdivision into BGC-I and BGC-II has gained acceptance in contemporary literature.

The Aravalli Mountain Range with Proterozoic successions of the Aravalli and Delhi systems (AravalliDelhi Mobile Belt: ADMB), encapsulates several independent geo-tectonic domains sharing between them stages of deformation and metamorphism.

The Paleoproterozoic age of the Aravalli Supergroup has been firmed up with new radiometric dates. The Aravalli Supergroup has been re-defined as (i) East Aravalli Terrane (EAT) of Nathdwara-Bhilwara-Hindoli and (ii) South-Central Aravalli Terrane (SCAT) of Nathdwara and Lunavada. No identifiable stratigraphic hiatus between the two terranes is discernable. The EAT is represented by medium to high-grade metamorphics with migmatised paragneisses and is affected by longitudinal shears making it challenging to establish a valid internal stratigraphic order. In contrast, the SCAT exposes un-metamorphosed to mildly metamorphosed sediments preserving well developed primary depositional structures, facilitating construction of a viable, although somewhat debatable stratigraphic order. Reassessment of stratigraphic position of the basal quartzite, basic volcanics and, paleosol units with the BGC helped to understand the stratigraphy of the Aravalli sedimentary pile in a new perspective. Inappropriate application of Lomagund-Jatuli heavy isotope event to assign an age to the Aravalli carbonate rocks is discussed. The possibility of two separate episodes of carbonate sedimentation events needed emphasis. Discussion included the use of the robust $U$ $\mathrm{Pb}$ dates in fixing the age of the Aravalli basin opening. The attention to the fallacy of using the age of Darwal Granite in assigning age to the Aravalli sedimentaries was drawn. Analyses of available structural and metamorphic data of the Aravalli Craton concerning the mobile belt was analysed.

The Delhi Supergroup is distributed either in a series of fault-bound basins in the northeast part of the Aravalli Mountain Range resting directly on the basement gneisses (North Delhi Fold Belt: NDFB) or directly overriding the Aravalli Supergroup of rocks in central and southwestern parts (South Delhi Fold Belt: SDFB). The stratigraphy of the NDFB is well constrained, but physical connection between the two belts is conjectural. The SDFB represents a collage of three independent linear fold belts, each with unique depositional and deformational attributes. The terrane between the extreme limits of NDFB and SDFB is occupied by undifferentiated granitic rocks. Both NDFB and the SDFB are made up of meta-arenites, carbonates, and pelites along with sporadic granites and gneisses. South of the main SDFB, an independent and possibly younger Sirohi basin, represents the final orogenic event in the cratonization of NW Indian shield. Geochronological data points to ca $1.72 \mathrm{Ga}$ and ca $1.0 \mathrm{Ga}$ ages for the collisional orogenies accompanied by polyphase deformation and metamorphisms. 
The plate tectonic models for the generation of the Aravalli and Delhi basins postulate the existence of a cratonic segment towards northwestern parts of the Aravalli Craton. The recent report of Eoarchean and Neoarchean zircon in the Delhi hinterland in the $N D F B$ indicates the existence of an elusive Marwar Craton.

\section{Introduction}

The Aravalli Mountain Range between Delhi and Lunavada in Gujarat is a spectacular $800 \mathrm{~km}$ long geomorphic feature in northwestern parts of the Indian Sub-continent that appear as a central midrib with vast expanses of the Thar Desert and Malwa Plateau towards west and east respectively. The 'higgledy-piggledy' mountain ranges constitute a significant water divide between the subcontinent's largest river systems (Ganga and Sindhu) along the Kailas-Girnar axis - Mount Girnar in Saurashtra and Mount Kailas in southern Tibet. The variable orographic trends engineer an overall distorted hourglass-like pattern for the mountain belt that shows constriction in the middle (north of Udaipur). The Aravalli Mountain Range represents not only the most ancient mountain chain of the subcontinent but also has the distinction of possessing a relatively well preserved record of about three billion years of earth's Precambrian evolutionary history ( $\sim 3.6$ to $\sim 0.6 \mathrm{Ga}$ ) encapsulated in three major chrono-stratigraphic polycyclic terranes, each having its unique history of cratonisation, basin development, deformation, metamorphism, magmatism and mineralization that allows their grouping under Basement Banded Gneissic Complex, Aravalli and Delhi supergroups, respectively.

The advent of the concept of plate tectonics facilitated a definitive shift in designating the regional Precambrian geological entities such as provinces, systems, blocks etc., to a more 'tectonogenic' terms like cratons (rigid, stable continental nuclei) and mobile belts (folded volcano-sedimentary basins together with magmatic intrusions that are ingrained and in tectonic contact with the cratons). Following this approach, the Precambrian rocks of the northwestern Indian shield consist of two broad domains (Fig. 1A), namely, Aravalli Craton (comprising Mewar Craton and Marwar Craton cf. Ramakrishna and Vaidyanadhan, 2010) and the contiguous Aravalli-Delhi Mobile Belts (ADMB). In the east, the Great Boundary Fault (GBF) separates the Aravalli Craton from the Bundelkhand Craton, although the two have been sometimes described together as a single entity. In the south, the craton abuts against the Son Narmada -Tapti Lineament marking the northern boundary of the CITZ. Isolated outcrops of Delhi rocks in the Indo-Gangetic Alluvium attest to the extension of the Aravalli Craton up to the foothills of the Himalaya. The Thar Desert has a lot of sparse outcrops. An enormous amount of newly acquired field and laboratory data is now available to evaluate geotectonic models that suggest the evolution of ADMB vis-à-vis Aravalli Craton to be a consequence of several episodes of either oceanic crust-continent interactions or their development within the craton under ensialic regimes.

The objectives of the present contribution are (i) to provide a brief review of the work carried out during the last century in unraveling the major Archean and Proterozoic events that are responsible in shaping the Aravalli Craton and its mobile belts; and (ii) to address the significant controversies and suggest viable alternatives.

\section{Aravalli Craton}

\section{Basement Granites and Gneisses}

The crystalline basement in Rajasthan and adjoining areas is represented by the 3.3-2.45 Ga old Archaean migmatite gneisses that have undergone spasmodic cycles of magmatism, deformation, metamorphism, and migmatisation spanning almost the entire Proterozoic Era and extends from the foothills of the Aravalli Mountain Ranges in the west, through plains of Mewar and up to the Great Boundary Fault in the east. Thus, the protracted and prolonged period of cratonisation of the Aravalli Craton spanned almost two billion years and finally culminated in the development of a variably deformed and metamorphosed composite gneiss-migmatite-granitoid complex. Gupta, (1934) and Heron, (1953) recognized the antiquity of this complex and referred it as a Banded Gneissic Complex (BGC) (Fig1). These discontinuous gneissic inliers in the middle of the Delhi fold belt on the western margin are also considered part of the BGC (Heron,1953).

In the east-central part, near Chittaurgarh, the BGC is in contact with a $140 \mathrm{~km}$ long and $25 \mathrm{~km}$ wide arcuate body of Berach Granite (Fig.1) earlier compared with the Bundelkhand Gneiss (Pascoe, 1950). Mainly made up of non-foliated homophanous pink granite, Berach Granite is chemically a rock of calc-alkaline sanukitoid affinity (Mondal and Raza 2013). While Pascoe (1950) called it the oldest basement rock (aka Fundamental Gneiss), Heron (1953) found it to be time-equivalent of the BGC, although the intrusive relationship with the schistose rocks towards the west was observed. Gupta et al. (1997) recorded intrusive relationship of this Granite with the metasediments of the Hindoli Group. Roy and Kroner,(1996) and Kaur (2016) have concluded that Berach Granite represents a pervasive terminal phase of cratonization activity in this region.

\section{Nomenclature of the basement rocks: Banded Gneissic Complex vs. Mangalwar Complex vs. Mewar Gneiss}

Gupta et al., (1997), based on primary edifice built by Raja Rao (1971), classified pre-Aravalli gneissic granitoids under Mangalwar Complex of Bhilwara Supergroup divisible into three subgroups and seven formations (lower: migmatite dominated Lasaria, Kekri, Manoki-Pal and Sarda formations, middle: migmatites and metasediments bearing Suwana and Potla formations and upper: metasediments with minor migmatites the Rajamahal formation).

Roy (1988) distinguished the pre-Aravalli granites and gneisses into (i) true pre-Aravalli granite-gneiss-amphibolite and (ii) syntectonically migmatized Aravalli metasediments. Roy (1988) called the 'true pre-Aravalli granite gneisses' as Mewar Gneiss, which is conventionally classified under the sensu-stricto BGC. On the other hand, Gupta et al. (1997) proposed another stratigraphic scheme for the basement gneisses following the Indian Code of Stratigraphic Nomenclature (CSNI: Balasundaram,1971). In this context, a careful look at the procedures laid down in the North American Code of Stratigraphic Nomenclature(NACSN1961: revised 1981 and 2005) will be of high relevance.The IUGS approved International Code of 


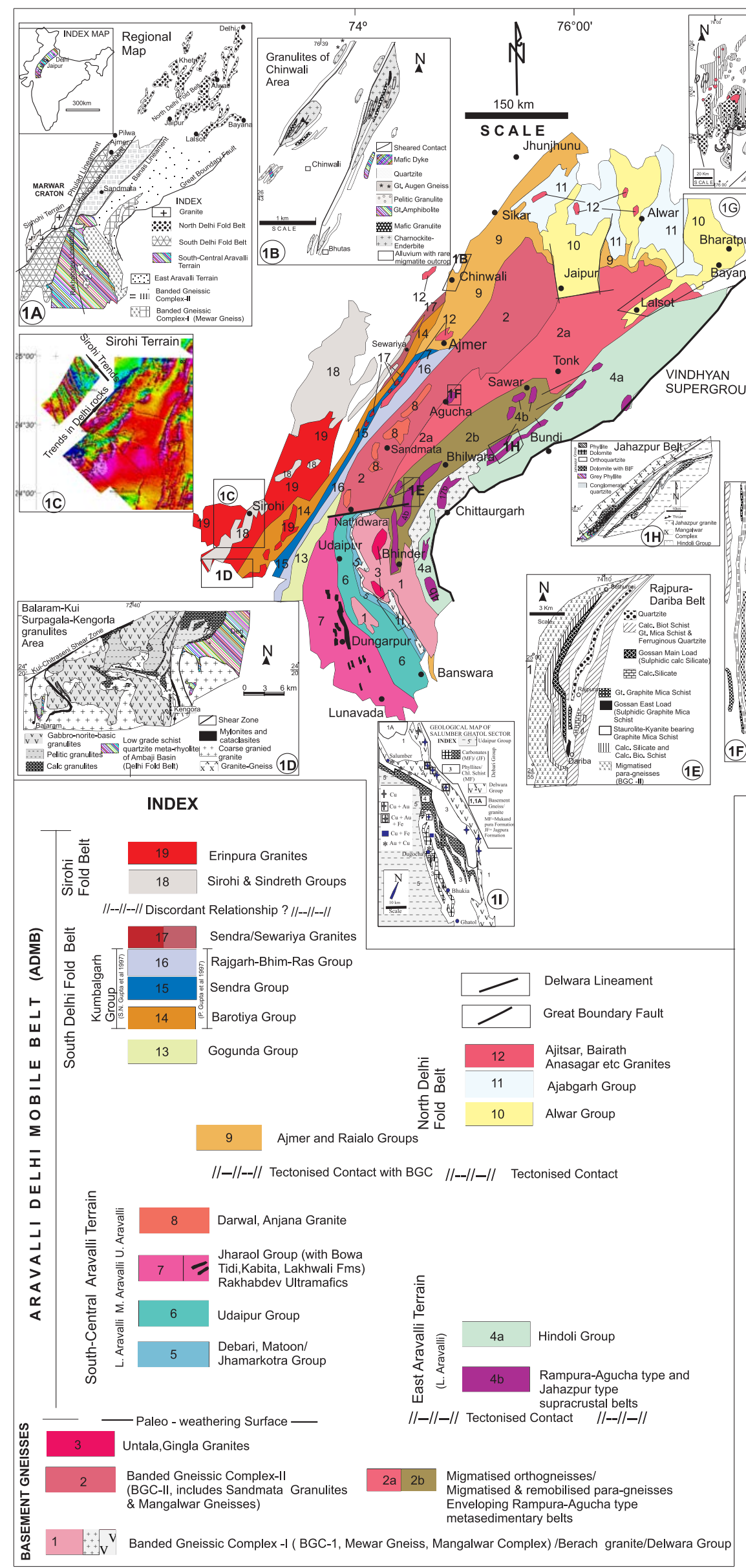

Stratigraphic Nomenclature (ICSN: Salvador, 1994; Murphy and Salvador, 1999), as well as NACSN emphasizes the use of lithodemic classification for the Precambrian terrain in addition to the lithostratigraphic subdivisions. (Easton, 2009; Kumpulainen, 2017). To quote: “A lithostratigraphic unit is defined as a body of stratified and tabular sedimentary, extrusive igneous, metasedimentary, or metavolcanic strata that is distinguished and delimited based on lithic characteristics, the stratigraphic position and conform to the Law of Superposition. The fundamental units are Formation, Member, and Bed. In contrast, a lithodemic unit is defined as a body of predominantly intrusive, highly deformed, and highly metamorphosed rock, distinguished and delimited primarily based on rock characteristics without conforming to the Law of Superposition.

The lithodemic units are the suite and the super suite. The lithodemic unit is defined by a geographic name in combination

Fig.1: Geological map of Aravalli Craton and its mobile belt (modified after Geological Survey of India map by Gupta et al. 1980, 1997) showing detailed geology of the critical sections.

(A) Sketch map showing craton-mobile belt configuration of the region; locations of the regional lineaments are after Gupta et al (1997). (B) Geological map of Chinwali area showing granulites tectonicallyjuxtaposed with the Delhi quartzites (after Fareeduddin et al., 1995); (C) IGRF corrected aeromagnetic map of Sirohi region showing regional NNW-SSE trend impinging on the NNE-SSW trending Delhi trend (after Gouda et al, 2015); (D) Geological map of Balaram-Kui-Surpagla-Kengora area (after Singh et al.,2010); (E) Geological map of Rajpura-Dariba belt (after Gupta et al, 1997); (F) Geological map of Rampura-Agucha area (after Gandhi et al, 1984); (G) Geological map of Lalsot-Bayana area (after Singh, 1988); (H) Geological map of Jahazpur area (after Malhotra and Pandit,2000); (I) Geological map of Salumber Ghatol area showing mineral prospects/deposits in the area (modified after Gupta et al 1997). 
with a descriptive or appropriate rank term. A 'complex' is a nonranked lithodemic unit and corresponds to a suite or super suite and is named and classified according to its geological context (structural and/or volcanic, etc.) and its geographic distribution. Lithodemic units are independent of geochronological attributes, although age relationships to other rock units have been taken into account.

Due to these Code constraints, the basement gneisses of Aravalli Craton need revaluation. It is observed that the term 'Banded Gneissic Complex’ (Heron, 1953), with thousands of square kilometers spread, is, in essence, a formal non-ranked lithodemic unit and therefore given a 'super suite.'status. The terms "Banded Gneissic" have an active "Geological context” but lack the critical criteria of 'Geographic context.' Because of such constraints implied in the Code,

- Lithostratigraphic grouping of migmatite gneisses and the metasedimentary relics into Mangalwar Group with its constituent 'sub-groups' and 'formations' (Prasad, 1982) is also untenable.

- The term 'Mangalwar Complex' is also not tenable since it defines a formal non-rank lithodemic classification unit correlatable to ‘super suite' but its internal subdivisions follow the lithostratigraphic nomenclature. Such intermixing of lithostratigraphic and lithodemic classifications is not appropriate in the stratigraphic code.

- On the other hand, the term "Mewar Gneiss' is neither a lithostratigraphic unit nor a lithodemic entity (as it does not define a formal rank).

The terminology of "Banded Gneissic Complex,” proposed about eight decades ago, for the basement gneisses of the Aravalli Craton comes nearest to satisfying the recent international stratigraphic codes. The only issue with this terminology is that it lacks geographic connotation. All the significant proponents of the classifications for the basement gneissic rocks (Heron, 1953; Gupta et al. 1997 and Roy 1988) have described the rocks from type sections in the Mewar region (Mangalwar also forms part of the Mewar region). Therefore, a prefix Mewar to the Banded Gneissic Complex (Mewar Banded Gneissic Complex) is likely to satisfy the requirements of the recent Codes. Sharma and Mondal, (2018)) argued that since the term 'Banded Gneissic Complex' partially satisfy the lithodemic classification, the name BGC gets the benefit of 'priority' (as per revised provision in the Codes) over the other titles.

\section{Sub-divisions in BGC}

Gupta (1934) suggested the BGC and BGC-like rocks occurring to the south and north of the Nathdwara near Udaipur as two distinctly different basement terrains (Fig.1). Accordingly, BGC- I in the southern and central part of Mewar is an undoubted Archaean basement underlying the Proterozoic Aravalli rocks. The BGC-II occurring towards the north of Mewar have a debatable basementcover relationship, and also, the unambiguous demarcation between BGC-I and BGC-II is not possible. Recent geochronological studies have indicated that the two BGC terrains have yielded markedly different radiometric dates (Please see Figure - 2 and references therein). The exact spatial distribution, their contacts, age, geological history and respective basement cover relationships within BGC-I and BGC-II has been a subject of prolonged debates (Sharma, 1988; Roy et al., 2005; Buick et al., 2006; Dharma Rao et al., 2011; Ahmad et al, 2016).
BGC-1: Essentially, the BGC-1 (Fig. 1) is a 3.3-2.45Ga composite gneiss-migmatite-granitoid displaying amphibolite-facies metamorphism (Heron, 1953; Sharma, 1988; Gopalan et al., 1990; Wiedenbeck \& Goswami, 1994; Roy \& Kröner, 1996; Wiedenbeck et al., 1996a). It consists of granite sensu stricto, granodiorite, trondhjemite, and tonalite carrying xenoliths of a variety of metasediments meta-igneous rocks dikes/sills of igneous rocks finegrained felsic rocks and pegmatites. Intermixture or interfoliar injection of different rock types resulted in the loss of distinctive original characters rendering the whole suite of metamorphosed, migmatized, foliated, and highly deformed rocks into a unique entity.

BGC-II: The BGC-II (Fig.1) is a Late Archean basement terrain providing a basement for the Palaeoproterozoic Aravalli cover rocks. This terrain has witnessed polycyclic reworking and extensive granite magmatism during much of the Proterozic time. Gupta (1934) described three significant constituents in BGC-II, namely (i) banded, dark biotite-gneiss alternating with light-colored pegmatitic/ apilitic rocks; (ii) medium and coarse-grained granites, and augen gneisses with recrystallised quartz, garnet, feldspar, sericite, chlorite and biotite and (iii) paragneisses with quartzite bands and schists. These constituent rocks are distributed in two distinct regional metamorphic terrains (Gupta et al., 1997). These are (i) amphibolite-facies supracrustals, amphibolites, and granitoids (tonalite-trondhjemitegranodiorite) gneisses ((Mangalwar Complex) and (ii) granulite-facies supracrustal strips and meta-igneous bodies (Sandmata Complex)., Sahai et al., (2008), Guha and Bhattacharya, (1995) have shown that the enclaves of granulite-facies Sandmata complex in amphibolites facies rocks and vice versa are not uncommon. Sharma and his coworkers (Sharma, 1988; Sharma et al. 1987) do not subscribe to this division of polymetamorphic rocks.

Sandmata Granulites: Owing to their crucial role in unraveling the Precambrian evolution of the Aravalli Craton, the polymetamorphites of Sandmata Complex remained dubbed in controversies. It represents an ensemble of pelitic granulite, calc-silicate granulite, and leptynite (quartzo-feldspathic gneiss) and gabbro (now two-pyroxene granulites) and norite. The megacrystic granitoid suite of charnockitic to enderbitic composition intrudes the granulites (Saha et al., 2008; Guha \& Bhattacharya, 1995; Dasgupta et al., 1997). Highly deformed ductile shear zones mark the contacts between the granulite and megacrystic granitoids/gneisses (Guha \& Bhattacharya, 1995).

Several ages (Fig. 2) for the Sandmata charno-enderbites are now available. With U-Pb zircon isotope dates, Sarkar et al. (1989) fixed the magmatic emplacement of charno-enderbite at $1.72 \mathrm{Ga}$. Fareeduddin and Kröner (1998) dated the granitoids from the Sandmata area by $\mathrm{Pb} / \mathrm{Pb}$ single zircon evaporation method at 1.69 Ga. The deformed granitoids of the Bhinai area with 1.62 to $1.69 \mathrm{Ga}$ dates point to a significant thermotectonic event (Wiedenbeck et al., 1996; Roy et al., 2005). Because of same magmatic and metamorphic recrystallization ages determined through the LA-ICP-MS U-Pb zircon method, Buick et al. (2006) placed both magmatic emplacement of charno-enderbite and granulite-facies metamorphism in the Sandmata at $1.72 \mathrm{Ga}$. They have also dated an amphibolite-facies overprint in the SMC and MC at 0.94-0.95 Ga using the same method.

Sharma and his coworkers (see Sharma, 1988 for references) and Bhowmik and his co-workers (see Sahai et al. 2008 for references) provided several exciting results related to the metamorphic events in this region. Sharma et al. (1987) asserted that the granulite facies 


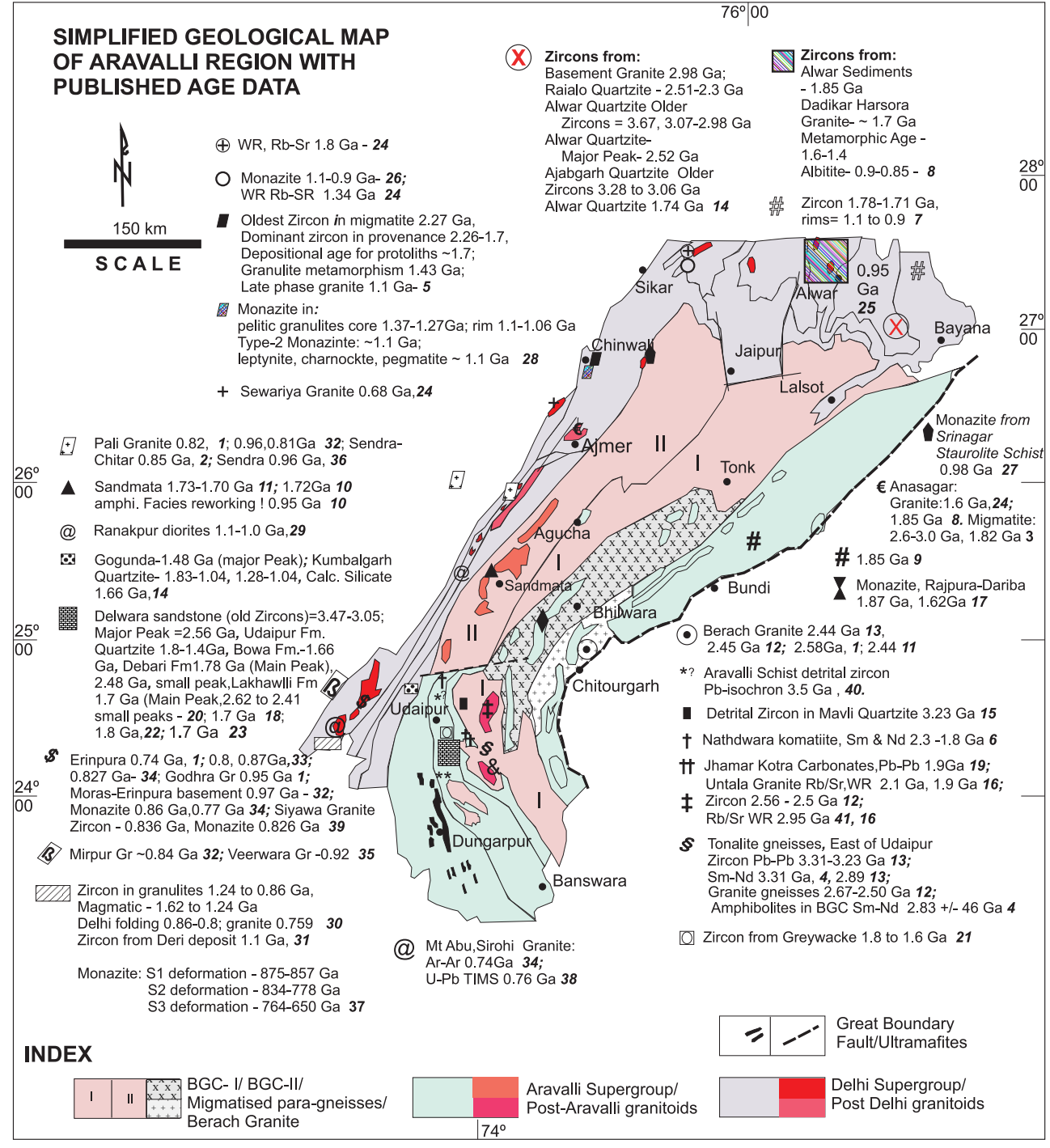

Figure- 2. Simplified geological map of Aravalli Craton and its mobile belt with published age data. The approximate location of the sampling is shown with a symbol and the source of data is indicated with bold italic numerals. The references cited are: 1 Crawford (1970); 2- Choudhury et al (1991); 3- Tobisch et al (1994); 4Gopalan (1990); 5- Fareeduddin and Kroner (1996); 6- Ahmed et al, (2008); 7- Biju Sekhar et al (2003); 8- Kaur et al (2017); 9- Deb et al (1989); 10Buik et al (2006); 11 - Bhowmik et al (2010); 12- Wiedenbeck et al (1996); 13- Roy and Kroner (1996); 14- Wang et al (2017); 15- Roy et al (2001); 16Choudhury et al (1982); 17- Hazarika et al (2017); 18- Banerjee and Russel (1992); 19- Sarangi et al (2006); 20Wang et al (2018); 21- Absar and Sreenivas, (2015); 22- Mckenzie et al (2013); 23- Deb and Thorpe 2004; 24Choudhury et al (1984); 25- Pant et al (2008); 26- Pandey et al (2013); 27- Bose et al (2017); 28- Bhowmik et al (2018); 29- Volpe and Macdonald (1990); 30- Singh et al (2010); 31Deb et al,2001.; 32- Zhao et al (2018); 33- Van Lente et al 2009; 34- Just et al (2011); 35 Purohit et al (2012); 36Pandit et al (2003); 37- Tiwari and Biswal....; 38-Ashwal et al (2013); 39Crawford, 1975); 40- Vinogrado et al (1964); 41 Gopalan, (1990b). metamorphism of the Archaean rocks of central Rajasthan is an outcome of second metamorphism (M2) related to Mesoproterozoic Delhi orogeny caused by magmatic underplating, transforming the crystalline basement into granulite and upper amphibolite facies. The P-T data on the granulites and the anticlockwise movement path of the rocks in a P-T diagram supports this model. The ductile shear zones facilitated the exhumation of granulites Sharma (1988) utilized the $1.7 \mathrm{Ga}$ and $2.29 \mathrm{Ga}$ ages for interpreting the rim and core compositions of zircon from charnockite-enderbite intrusion (Sarkar,1989). He suggested that partial melting during granulitefacies metamorphism was under water-deficient conditions at depth, and the melt was produced from partial melting of the basement rocks and not by fractionation of the underplated magma. He concluded that the metamorphic events at Sandmata are parts of the ensialic orogenesis of the Aravalli Craton.

On the other hand, Bhowmik and his co-workers ( (Sahai et al., 2008 for references) conclude differently: stating that the

Sandmata region recorded three distinct tectonothermal events: (i) an older, medium-pressure granulite-facies metamorphic event (M1) in the sillimanite stability field, which is registered only in the enclave, (ii) a younger, kyanitegrade high-pressure granulite-facies event (M2), common to all the litho-associations of the area, and (iii) a terminal amphibolite-facies metamorphic overprint (M3). The high-P granulite facies event has a clockwise $P$-T loop with a wellconstrained prograde, peak (M2, $P \sim 12-15 \mathrm{kbar}, \mathrm{T} \sim 815^{\circ} \mathrm{C}$ ) and retrograde $\left(M 2 R, \sim 6.1 \mathrm{kbar}, T \sim 625^{\circ} \mathrm{C}\right)$ metamorphic history. M3 is observed only in late shear zones. Using the geochronological data (Fig.2) and P-T estimations,this research group suggested amalgamation of two crustal blocks during a collisional orogeny. The M3 reactivation is inferred to be of Calymmian (Grenvillian) age.

Sandmata-like Terrain in Trans-Aravalli Region- The PilwaChinwali granulites: Fareeduddin and his co-workers (see Fareeduddin, 1995 for references) reported granulite to upper amphibolite facies litho-associations of calc-silicate granulite, garnetcordierite granulite, often orthopyroxene-bearing, leptynite gneiss, garnetiferous charnockite, garnetiferous two-pyroxene granulite, and garnetiferous amphibolite from Pilwa-Chinwali areas northwest of Ajmer (Fig. 1B). These granulite facies rocks occur as tectonic slices in the intermontane areas at the northwestern fringe of the Delhi fold belt proximal to- or west of the main Aravalli mountain range, and therefore the area could be considered as representing the Trans- 
Aravalli Region.

Though the preliminary P-T estimates of the co-existing mineral phases have indicated retrogressive pressure of $5.77 \mathrm{~kb}$ and $4.04 \mathrm{~kb}$ and temperatures of about $650^{\circ} \mathrm{C}$ and $525^{\circ} \mathrm{C}$ for charnockite's core and rim compositions and $9.5 \mathrm{~kb}, 7.5 \mathrm{~kb}$, and $5.5 \mathrm{~kb}$ and temperatures of about $630^{\circ} \mathrm{C}$ metapelites (Fareeduddin et al.,1994), a more detailed study by Bhowmick et al, (2018) has shown a medium-pressure granulite facies metamorphism ( $P$ between 4.9 and $6.8 \mathrm{kbar}, T>760$ $815^{\circ} \mathrm{C}$ ) along a heating-cooling, counterclockwise $P-T$ path.

The ${ }^{206} \mathrm{~Pb} /{ }^{207} \mathrm{~Pb}$ data from the magmatic zircon in charnockite (Fig. 2) that intruded during the peak of the granulite facies metamorphism yielded an age of 1434.3 $\pm 0.6 \mathrm{Ma}$. Six detrital zircons from pelitic granulites yielded ages between $1522 \mathrm{Ma}$ and $1000 \mathrm{Ma}$ since the youngest zircon deposited in the basin is $1000 \mathrm{Ma}$, the gneissic fabric forming event and the second phase of granulite facies metamorphism, therefore, are distinctly younger and a post-1000 Ma event. The magmatic zircon in Pilwa granite yielded an age of $1128 \pm 0.7$ Ma (Fareeduddin and Kröner, 1998). Chemical dating of 21 monazite grains (Bhowmick et al. 2018) from six Pilwa-Chinwali granulites samples recorded three broad age domains: (1) $1305 \pm 25 \mathrm{Ma}$, being the age of older metamorphism from detrital remnant in the pelites (2) between $1085 \pm 10 \mathrm{Ma}$ and $1010 \pm 20 \mathrm{Ma}$ reflecting the timing of granulite facies metamorphism and (3) $880 \pm 35$ Ma linked with the timing of Erinpura granite magmatism. While collating the age determinations-vis-à-vis metamorphism by zircon and monazite dating, Bhowmik et al., (2018) proposed:

- $\quad 1.43$ Ga charnockite has three possible explanations: (i) it was emplaced at ca. 1.72 Ga (age of Sandmata enderbite) and re-metamorphosed between $1.09 \mathrm{Ga}$ and $1.01 \mathrm{Ga}$ implying ca. $1.4 \mathrm{Ga}$ date represents a partially reset age; (ii) it represents the timing of a Mesoproterozoic high-temperature magmatic event, hitherto unrecognized from other domains of Aravalli Delhi Mobile Belt; (iii) the 1.43 Ga zircon represents pristine or differentially reset inherited component in the magmatic rock.

- 1.3 Ga age monazite suggests (1) age of older metamorphism or (2) represents a detrital remnant, which wholly or partially survived dissolution in anatectic melt produced during the 1.09-1.01 Ga metamorphic event;

- Both the zircon and monazite data suggests that there is a broad $~ 1.1$ Ga granulite facies metamorphism.

Mode of occurrences, lithologic assemblages, and metamorphic recrystallization events largely mimic the Sandmata terrain and, therefore, could be construed as the existence of Sandamata like terrane across the Trans Aravalli region.

\section{Antiquity of Banded Gneissic Complex vs. Aravalli Supergroup}

There had been a prolonged debate as to whether BGC, on its entirety or at least a part of it, is the result of migmatisation of the preexisting metasedimentary and meta-igneous formations. But the moot question is whether such precursor sediments are coeval to (or part of) the Aravalli metasediments or they represent a distinctly different older depositional facies.

Crookshank, (1948) visualized that the gneissic complex is the result of the poly-phase intrusion of granitic material into the Aravalli schists. This contention, in essence, suggests that the Aravalli rocks are older than the BGC. Extensive structural studies by Naha and his co-workers (, see Naha and Mohanty,1990 for references) on the BGC as well as Aravallis suggested the Aravalli sequence was syntectonically 'granitized' on a large scale around Nathdwara, Amet and Salumbar to produce BGC.

Heron (1953) recognized dark, highly foliated biotite and chloriteschists bands as relics of older metasediments in the BGC. He argued that the quartzitic rocks to the northwest and west of Amet and metapelites to the west of Antalia represent enclaves of primitive precursor metasediments. These early phase sediments are distinctly different from the thick meta-sedimentary sequence of Aravalli succession (Heron,1953 p.10), which suggests the existence of two distinct metasedimentary phases, of unclassified metasedimentary ancient supracrustals, and the thick sequences of Aravalli Supergroup.

Greenstone-like sequences in BGC: By comparing the geotectonic attributes of Dharwar Craton with the Aravalli Craton, the presence of two generations of greenstone belts could be identified. It helped in identifying (i) dismembered greenstone sequences from within the BGC and (ii) large linear belts overlying the BGC with greenstonelike features.

Upadhyaya et al. (1992) and Roy and Jhakar (2002) reported dismembered remnants of Archean "greenstone belt" from the Jagat and Rakhiawal area towards southeast and northeast of Udaipur, respectively although these 'large disjointed bodies' are only few few hundreds of meters long hence do not qualify for this nomenclature. The 'greenstone belts defined as linear belts extend for several 10s (if not hundreds) of kilometers. Jagat-Rakhiawal supracrustals may represent an ancient supracrustals similar to the Sargur supracrustals in the Dhawar Craton. The primitive komatiitic chemistry of the early mafic igneous bodies (Ahmad et al.2008) further strengthens the recognition of these as 'ancient supracrustals.' Sinha Roy et al. (1998) identified two types of greenstone sequences in BGC, the older Sawdri Group with komatiite, ultramafite, chert, basic tuffs and carbonates, and a younger Tanwan Group of greywacke, amphibolites, and carbonates. Sinha Roy et al. (1993) envisaged a large scale granite-greenstone assemblage in the basement rocks of the Aravalli Craton with two-tier development accompanied by widespread migmatisation. The ductile shear zone (DSZ) along which the reworked granite-greenstone (primary) belt of the Mangalwar Complex got emplaced marks the terrain margin and tectonic slivers of granulite facies rocks of the Sandmata Complex. The Hindoli Group is a secondary greenstone belt which is juxtaposed with Mangalwar terrane with a prominent DSZ.

\section{Geochronological studies on BGC and Search for the oldest rocks in Aravalli Craton}

Archean antiquity of the Aravalli Craton is known as it compares well with other cratons of the Peninsular Indian shield. The first direct evidence for this antiquity became evident from 3.5 Ga isochron age for detrital zircon from Aravalli schist (Vinogradev et al. 1964) and $\mathrm{Rb} / \mathrm{Sr}$ whole-rock isochron age of $2.95 \mathrm{Ga}$ for Untala and Gingla granites east of Udaipur (Choudhury et al. 1984). Preliminary Sm/ $\mathrm{Nd}$ dates of the host gneisses and amphibolites indicate a $3.5 \mathrm{Ga}$ time frame (MacDoughal et al. 1983). The oldest detrital zircon, with an age of $3491 \pm 7 \mathrm{Ma}$, comes from the Delwara Formation (McKenzie et al. 2013). Gopalan et al. (1990) reported a Sm-Nd isochron age of $3.31 \pm 0.07 \mathrm{Ga}$ and an initial Nd isotopic ratio that is close to chondritic 
values for tonalitic to granodioritic gneisses from the basement gneiss of the Ahar River Section in the type area of the Aravalli Supergroup. They also reported a younger isochron age of $2.83 \pm 0.05 \mathrm{Ga}$ and small positive initial $\varepsilon_{\mathrm{Nd}}$ for lenticular mafic amphibolites within the gneisses. This value is closer to $2.95 \mathrm{Ga}$ age for the Untala type granitoid. Similarities in the ages of gneisses and associated amphibolites suggest that mafic volcanism is associated with the formation of the granitic protoliths. Roy et al. (2012) reported single zircon ‘evaporation' age of $2905 \pm 0.3$ Ma for granite gneiss from Nathdwara area. This age compares well with the age of $\sim 2887 \mathrm{Ma}$ for a granite gneiss from the Archaean basement outcrop southeast of Udaipur (Roy and Kröner, 1996). U-Pb-Hf isotope studies by Kaur et al. (2019) reveal that the TTG precursors of gneissic complex intruded during the Paleoarchean (3310 Ma) and Neoarchean (2563$2548 \mathrm{Ma}$ ) times. More recently, Wang et al. (2017) reported zircon $\mathrm{U}-\mathrm{Pb}$ crystallization age of $2985 \mathrm{Ma}$ for twelve grains with oscillatory cores from basement granite underlying the Raialo Group in northeast Rajasthan. Further, $2532 \pm 27$ to $2309 \pm 30$ Ma old subhedral to subrounded zircon from Raialo Group contain subchondritic $\varepsilon \mathrm{Hf}(\mathrm{t})$ values (-0.1 to -5.3$)$, corresponding to two-stage hafnium model ages (TDM2) of $3.3-3.0 \mathrm{Ga}$.

Several geochronological studies (Fig. 2) established that the bulk of the BGC represents 3.0 Ga to 3.3 Ga crust and has evolved under a polycyclic regime, between Paleo- to Mesoarchean time. Wiedenbeck et al. (1996) reported ion microprobe ${ }^{207} \mathrm{~Pb} /{ }^{206} \mathrm{~Pb}$ zircon dates from six samples from the southern Aravalli Range that yielded precise crystallization ages between $2562 \pm 6$ and $2440 \pm 8$ Ma (1б) for four granitoids. A single sample of gneiss gave an age of $2502 \pm$ $4 \mathrm{Ma}$. This study, together with other geochronological studies for the Berach Granite (Fig. 2) (Crawford, 1970; Roy and Kroner,1996; Kaur, 2016) indicated age bracket of 2.44 Ga to 2.58 Ga for the endNeoarchean craton stabilization event.

Eoarchean Crust in the Aravalli Craton: Wang et al. (2017) utilized in situ U-Pb and Hf isotopic data for detrital zircon to constrain not only the early crustal evolutionary history but also interpret the crucial relationship between the Proterozoic Aravalli and Delhi fold belts. The subhedral to subrounded zircon grains with characteristic oscillatory zoning and uniform internal structure appeared derived from the Alwar Quartzite from northeast Rajasthan. Late Archaean to early Palaeoproterozoic zircon grains with an age peak at c. $2.52 \mathrm{Ga}$ are the dominant population in this sample. Ages of other zircon range between 3070 - $2980 \mathrm{Ma}, 2808$ - $2683 \mathrm{Ma}, 2350 \pm 24 \mathrm{Ma}$, and 2110 \pm 33 Ma while a single zircon grain yielded a ${ }^{207} \mathrm{~Pb} /{ }^{206} \mathrm{~Pb}$ age of 3671 $\pm 15 \mathrm{Ma}$. This grain is subhedral and shows well-preserved oscillatory zoning and $\mathrm{Th} / \mathrm{U}$ ratio of 0.98 which implies its igneous origin. The oldest zircon has a $\varepsilon H f(t)$ value of +0.1 and TDM2 of $3.9 \mathrm{Ga}$. The youngest zircon has the lowest $\varepsilon \mathrm{Hf}(\mathrm{t})$ value of -12.1 with TDM2 of 3.6 Ga, close to the oldest age of $3.67 \mathrm{Ga}$, the first Eoarchaean age determined in NW India which suggests that such an old crust is also present within Peninsular India. This study shows the provenance of sedimentary detritus for Alwar Quartzite was the hinterland of NW India.

\section{Aravalli Mobile Belt}

Basement-cover relationship: Hacket's (1877) early geological traverses laid the foundation to the systematic geological mapping in the region by Gupta (1934), Coulson (1933) and Heron (1953). The latter, a seminal work referred extensively during last seven decades, broadly classified the rocks contained in the Aravalli Mountain Range as belonging to Aravalli and Delhi systems that overlie unclassified granites, gneisses, and migmatites exposed in the contiguous plains belonging to the Banded Gneissic Complex (BGC). Like many strongly deformed Proterozoic fold belts, the basement-cover relationship between the Aravalli supracrustals and the BGC was found to be contentious. Heron (1953) gave a passing reference to the antiquity of the Aravallis. However, it was Naha and Mohanty (1990) who advocated the granitization of the Aravalli sequence, which led to the formation of the BGC. The later workers refuted this interpretation (Sharma, 1988; Roy, 1998; Gupta et al. 1997). Roy et al. (1993) reported the unconformable relationship between Aravalli and BGC all along the entire margin of the Aravalli fold belt, prominently displayed in the eastern margin. Strips of meta-aluminous oxidized paleosols occur at the basement-cover interface (Banerjee, 1996; Pandit et al. 2008). Banas Dislocation Zone, a reactivated dextral strike-slip boundary fault of the Aravalli rift basin, separates the Hindoli belt (possibly a greenstone belt) from the basement gneisses in the north and Berach Granite-gneiss in the south. Currently, there is a near consensus that the BGC constitute the basement for Aravalli supracrustals. Another nagging issue in the basement-cover studies is the status of the Delwara volcanic believed to be part of the Aravalli Supergroup. The geochemical affinity of these volcanics with those occurring in the interiors of the Archean BGC favors their co-genesis and contemporaneity (Banerjee and Bhattacharya, 1994; Ahmed and Tarney, 1994; Raza and Khan, 1993).

Stratigraphy: The Aravalli rocks are known to occur (i) within an inverted V-shaped basin from south of Nathdwara to Lunavada and (ii) in linear disconnected basins that occur within migmatised paragneisses from northeast of Nathdwara to Bhilwara-Hindoli areas (Fig.1). The two terrains are connected with chicken-neck configuration near Nathdwara by Delwara Dislocation Zone (Sinha Roy et al.1998). Raja Rao (1971) proposed that Bhilwara-Hindoli metasedimentary belt belongs to an earlier cycle viz Bhilwara Group (later elevated to Supergroup by Gupta et al., 1997) thereby evoking the idea of the diachronous origin of the Aravalli supracrustal belts along with BGC. Whereas there is a consensus regarding the existence of Aravalli rocks well within the Nathdwara-Lunavada basin (referred to as 'Aravalli type area'), divergent views exist regarding the stratigraphic status of the supracrustals in Nathdwara-BhilwaraHindoli tracts. The pelite-carbonate association with black shale and chert intercalations in these belts prompted Heron (1953) to correlate them with the Raialos. Gupta et al. (1997) included them under the youngest unit of Bhilwara Supergroup, Sinha-Roy (1998) described them as Aravalli equivalent isolated cover sequences and Roy and Jhakar (2002) considered them as cover rocks of Aravalli Supergroup.

The bulk lithologies of the cover rocks in the 'Aravalli type area' and those in the Bhilwara sector are mostly similar (Heron, 1953; Roy et al., 1988) with no significant structural hiatus between the two. The Berach Granite initially considered the basement for the Aravalli supracrustals displayed an intrusive relationship with the eastern tracts of the Aravalli Supergroup (Raja Rao et al. 1971). In Udaipur area, Ahar River granite acted as the floor for the Aravalli sedimentaries (Dutta, 1980, fig.5). Since the cover sequences are separated only in space and not necessarily in time, we refer to the Aravalli supracrustal belts of the Nathdwara-Bhilwara-Hindoli area as East Aravalli Terrain (EAT) and those between Nathdwara-Udaipur- 
Lunavada areas ('Aravalli type area’) as South-Central Aravalli Terrain (SCAT, Fig.1).

East Aravalli Terrain (EAT)-Nathdwara-Bhilwara-Hindoli sector: The meta- volcano-sedimentary belts (Rajpura-Dariba, RampuraAgucha type belts) in this sector occur in two forms: (i) as extremely stretched, attenuated strips of medium to high-grade metasediments that occur amidst migmatised paragneisses (Fig.1); these are deeply dissected by longitudinal shears that preclude deciphering a valid standard internal stratigraphic order that could be reasonably applicable to the other disconnected basins (see Figs.1E and $1 \mathrm{~F}$ ) and (ii) about $400 \mathrm{~km}$ long stretch of arcuate low-grade metamorphic belts with well defined litho-stratigraphic order, that occurs towards eastern extremity of the ADMB and referred to as Hindoli-Jahazpur belts. A detailed description of all the supracrustal belts in this terrain is beyond the scope of this paper, however salient points of a few of the belts are provided here.

The Rampura-Agucha Belt, located about 75 km SSE of Ajmer (Fig.1F), hosts a world-class $\mathrm{Pb}-\mathrm{Zn}$ deposit and exposes high metamorphic grade rocks like pyroxene granulites, garnetiferous feldspathic sillimanite gneiss, garnetiferous amphibolites, metapelites, calc-silicates, and massive to semi-massive ore zones. The seventeenkilometer long, spindle-shaped Bethumni-Sindeswar-Rajpura-Dariba belt, located at about $75 \mathrm{~km}$ north-northeast of Udaipur (Fig.1E), occurs within migmatised gneisses. The belt consists of quartzite, siliceous dolomite, calc-pelite, and garnet-staurolite and kyanite bearing meta-pelite. About $12 \mathrm{~km}$ long and $6 \mathrm{~km}$ wide co-axially folded isolated Sawar basin, located at about $50 \mathrm{~km}$ east of Agucha. A repetitive sequence of carbonate and pelitic schist with fairly extensive quartz veins overlies the BGC. Located about $50 \mathrm{~km}$ southeast of Ajmer, the Sawar-Bajta belt exposes medium-high grade metamorphic assemblages (sillimanite bearing metapelites and diopsidic marble) that are affected by three phases of folding where (i) refolding $\left(F_{2}\right)$ of $F_{1}$ folds results in plunge inversions and (ii) late ductile shear zones truncate the late $F_{3}$ folds (Ray, 1988). The JahajpurHindoli Belt occurs towards the north-eastern part of the gneissic terrain near Bundi. Malhotra and Pandit (2000; Fig.1H) classified the belt into two, the western sub-belt comprises conglomerate, quartzite phyllite dolomite with BIF, and bimodal volcanic and the eastern belt has the same formations sans litho units above the dolomite. The conglomerate directly overlies Jahajpur granite. The first three belts mentioned above exhibit middle to upper amphibolite facies metamorphism, while the easternmost belt (Jahajpur-Hindoli) exhibits greenschist facies metamorphism.

South-Central Aravalli Terrain (SCAT) - the NathdwaraUdaipur-Dungarpur-Banswara-Lunavada sector: Heron (1953) identified six major litho-marker units within the Aravalli System of this sector: (i) amygdaloids and epidiorites (ii) arkose and conglomerates (iii) phyllites and biotite schist (iv) quartzites (v) carbonaceous band east of Udaipur city and (vi) limestones. The bulk of the Aravalli succession represents two sedimentary packages of the marine shelf and deepwater facies that facilitated its division into lower and upper Aravallis, respectively, with Rakhabdeo Lineament marking a tectonic contact between the two (Poddar and Mathur,1967). Banerjee et al. (1971 a, b), for the first time published a formal stratigraphic succession of the 'Aravalli Group' with three distinct formations, Debari, Matoon, and Udaipur unconformably overlying the BGC. With detailed geological mapping the status of Aravalli
Group was elevated to Aravalli Supergroup (Gupta et al., 1997) along with proposals of 3-fold (Sinha Roy et al. 1998), 5-fold (Banerjee and Bhattacharya, 1994), 6-fold Gupta et al. (1997) and 8-fold (Roy and Jhakar, 2002) classification schemes. The plethora of stratigraphic systems (Fig-3) created confusion, and it is evident that the available stratigraphic schemes contradict one another regarding age, the aerial extent of the groups/formations, ambiguous basement-cover relationship and by using the same geographical name for the rocksuites that are dissimilar in their litho contents. However, irrespective of (i) lithostratigraphic level accorded (group vs formation) (ii) conflicting internal organization (eg. Debari appearing at different stratigraphic levels) and (iii) nomenclature and their semantics (Matoon vs Jhamarkotra) the most conspicuous feature of the SCAT, acknowledged by all the workers, is the record of (i) reasonably extensive mafic volcanism just prior to the basin initiation (ii) overlain by two extensive and successive outcrops of sedimentaries manifested in thick marine shallow-water clastic-chemical sediments at the base and deep-sea greywacke-phyllite sediments at the top. Accordingly, the sub-divisions of the Aravallis of South-Central Aravalli Terrane proposed in this contribution are shown in Fig.1.

Aravalli Sequence in the 'type area': The Delwara Formation in the type-area near Udaipur is a thick sequence of volcanic rocks generally referred to as Delwara-Nathdwara volcanics. Recent geochemical and geochronological data indicate that these are komatiitic and tholeiitic in composition, which erupted between 2300 and $1800 \mathrm{Ma}$ from enriched and heterogeneous mantle source regions being part of the sub-continental lithospheric mantle of the Aravalli Craton (Ahmad et al., 2008; Khan et al., 2005).

The sedimentary succession began with a rock unit of the paleoweathering surface followed upward by the arenite, quartz-pebble conglomerate, and cross-bedded rippled and medium-grained quartz arenite of the Debari Formation (Debari Group of Gupta et al., 1997). The overlying Matoon Formation (Jhamarkotra Formation of Roy et al., 1988) with black-shale, dolomite, and stromatolitic phosphorite and Udaipur Formation (graywackes, phyllites, and localized flysch type conglomerates representing a distal deeper-shelf facies are directly correlatable to the composite Udaipur and Bari Lake Formations (Gupta et al. 1997). Micritic carbonates, invariably recrystallized and transformed into marble, with no shallow water sedimentary features, constitute a distinct carbonate facies. The stratigraphic position of these carbonate successions is disputable. It appears that these carbonate rocks are older than the stromatolitic phosphorites and dolomites exposed in other parts of the Girwa valley. Laminated, turbidite related metapelites of the Jharol Group constitute the youngest stratigraphic unit of the Aravalli Supergroup. Serpentinized ultramafics along the Rakhabdeo Lineament are taken as the boundary between the shelf facies and deep water facies of Aravallis, although this contention is a subject of debate as slivers of altered ultramafics also occur as detached outcrops within the Jharol Group of rocks (Fig. 1; Gupta et al.1997).

Two Different Carbonate Stratigraphic units: Recently, all the carbonate rocks of Jhamarkotra-Matoon-Kanpur-Rama-Nathdwara areas (Jhamarkotra Formation) have been re-assigned a depositional age of 2.2-2.0 Ga (Roy and Jakhar 2002) on the basis of anomalously $\delta^{13} \mathrm{C}$-enriched carbonates of the Nathdwara-Rama sector correlated with the Lomagundi-Jatuli isotope excursion of 2.3 and $2.05 \mathrm{Ga}$ (Schidlowski et al. 1976; Melezhik et al., 2007). However, the 

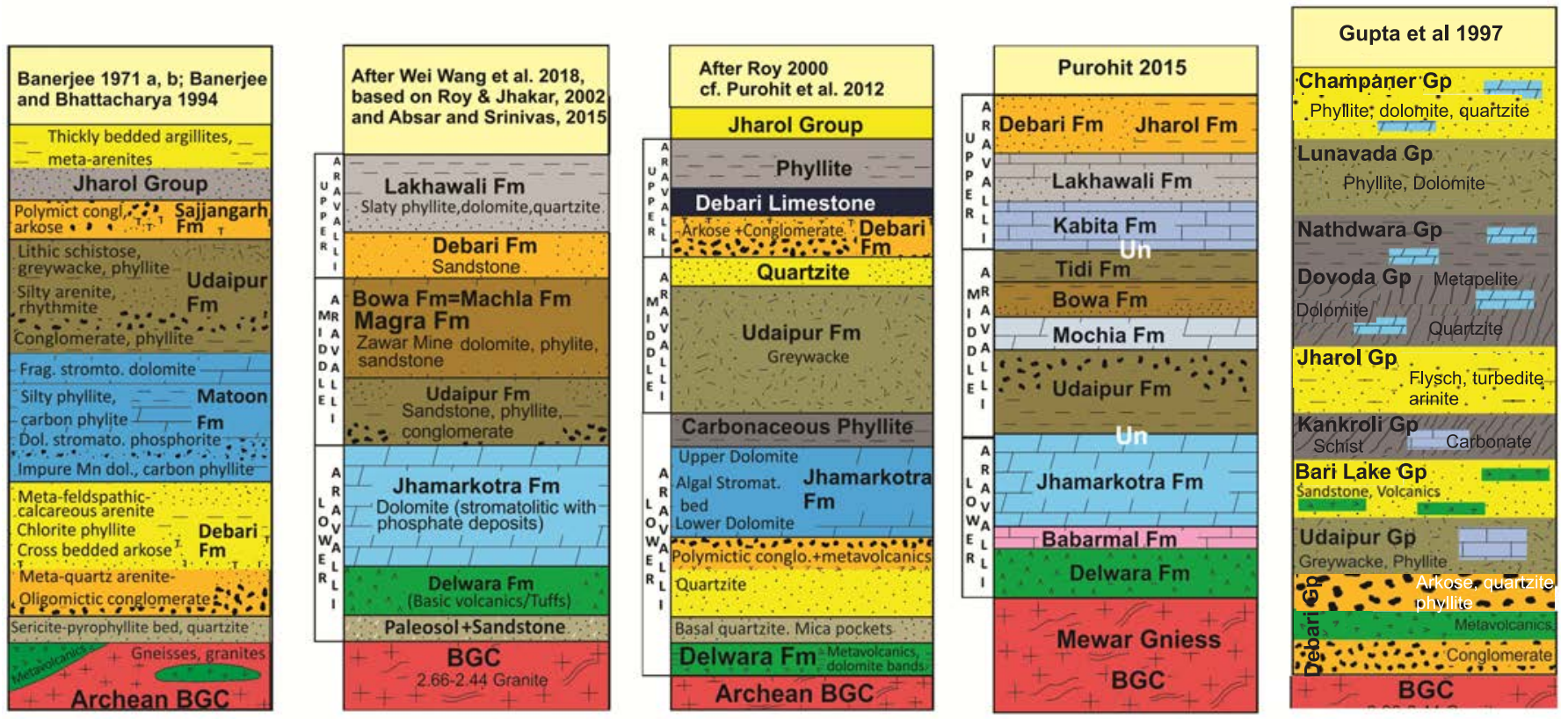

Fig. 3: Stratigraphic schemes proposed for the Aravalli Supergroup between Nathdwara and Lunavada.

dolomite-marble rocks of the Nathdwara-Rama sector displaying positive carbon isotope values are never seen in continuity with the phosphorite and dolomite beds of Jhamarkotra-Matoon-KanpurDakankotra areas which analyzed near zero per mil values for the carbonate carbon along with and heavy organic carbon (Banerjee et al., 1986; Sreenivas et al., 2001; Wei Wang et al., 2018). The 1.9-1.7 Ga detrital zircon ages of the lower Aravalli rocks at the base of the phosphorite-dolomite units of the Matoon/Jhamarkotra Group (Fig. 2; McKenzie et al., 2013) convincingly contest the claims that $\ddot{a}^{13} \mathrm{C}$ enrichments in the non-phosphatic, non-stromatolitic dolomite and marbles of the Nathdwara-Rama-Ghasiar regions possibly showing the effects of the $2.1 \mathrm{Ga}$ Lomagundi-Jatuli event is applicable to all the carbonate successions in the region. Papineau et al.,(2009) tried to explain this anomaly and postulated two penecontemporaneous sub-basins (of the same age) within the Aravalli sea, where micritic dolostones and marbles of Rama-Nathdwara sector and the stromatolitic dolostones of Jhamarkotra-Kanpur-Matoon sector formed simultaneously in the same epeiric Aravalli basin. In other words, it was interpreted that all carbonate-phosphate strata deposited contemporaneously around $~ 2.2$ Ga. Non-recognition of any synsedimentary fault or evidence of any basement onlap of the strata does not support such a postulation. Marked lithostratigraphic, petrological, and geochemical dissimilarities between carbonates of the proposed "sub-basins" indicate that these sedimentary units were either laterally discontinuous due to facies change or that each "subbasin" was a separate depositional system which was active at different periods of the Proterozoic history. McKenzie et al., (2013) tentatively suggested that the Jhamarkotra (=Matoon) Formation comprising phosphorite-dolomite beds and non-stromatolitic carbonates might have hosted a previously unidentified late Paleoproterozoic positive $\mathrm{a}^{13} \mathrm{C}$ excursion. It is, however, more appropriate to assign two different time frames for these two isotopically different carbonate successions, one in the north and the other in the south of the Girwa Valley. Comparison of the isotopically heavy carbon dolostone-marble with the pink marble-dolostone unit stratigraphically and physically below the stromatolitic dolomite (Babarmal Formation of Gupta et al. 1997 and Purohit et al. 2012) is significant and indicates an older age for the isotopically heavy carbonate units.

Aravalli succession in Salumber-Bhukia-Ghatol section: The Salumber-Bhukia-Ghatol segment in the Udaipur-Banswara region of Rajasthan show promising indications of gold and base metal sulfide mineralization (Figure 11). Located $130 \mathrm{~km}$ ESE of Udaipur, it represents the southeastern extension of the stratigraphic units of the Aravalli type-section (Heron, 1953). Towards the southeast margin, near Salumber, the volcanic rocks are high-Mg tholeiitic basalts and komatiites that reflect enriched LREE and incompatible elements (similar to continental tholeiites or P-type MORB; Shekhawat et al., 2007). The quartzite/conglomerate at the base directly overlies the BGC belong to a well developed Debari Group of rocks. Dolomite and phyllites/carbon phyllite with intercalations of mica schist represent the locally designated Mukundpura Formation while the Jagpura Formation consists of meta-pelites and dolomitic marble.

Banerjee and Bhattacharya (1989; 1994, pp.26-32) had suggested that the rocks of Aravalli Supergroup archive the records/ for the development of early Paleoproterozoic passive-margin platform sedimentation, followed by a transition to continental arc and subsequently to an evolved riftbasin-passive-margin setting and depositional history using petrology, petrofacies and trace element geochemistry of the clastic rocks of the Aravalli succession as the proxy data set. Recently, Wang et al. (2018) evaluated the sandstone compositions of the lower, middle, and upper Aravallis and came to the same conclusion and interpreted the same tectonic setting and depositional history.

\section{Structure and Metamorphism}

The East Aravalli Terrain: The metasedimentary belts that occur close to the BGC show higher metamorphic impress. In the RampuraAgucha area, Deb and Sehgal (1997) have reported peak geothermobarometric values of $650^{\circ} \mathrm{C}$ at $6 \mathrm{~kb}$ for garnet-biotite and garnet-hornblende pairs, as well as sphalerite-hexagonal pyrrhotite- 
pyrite and garnet-plagioclase-sillimanite-quartz assemblages. Fareeduddin et al. (2014) reported values of $677^{\circ} \mathrm{C}$ and $4.01 \mathrm{~kb}$ for the garnet-biotite thermometer and the garnet-sillimanite-quartzplagioclase on a sample collected from the Agucha mine. In the Bethumni-Sindeswar belt, a temperature range of $580^{\circ}-600^{\circ} \mathrm{C}$ with corresponding pressure of 5.5 to $6.1 \mathrm{~kb}$ is recorded inside the kyanite field (Mishra et al., 2006).

The South-Central Aravalli Terrain: Excellent structural studies in this sector (Sen, 1980; Naha and Halyburton., 1974; Roy et al., 1988, and references therein; Sinha-Roy et al. 1993) paved the foundation for detailed studies by later workers.

A classic example of polyphase folding on a regional scale is that of a 'hammerhead syncline' in the Kankroli-Rajnagar-Nathdwara sector near Udaipur, which is also a critical type-locality for studying the stratigraphic relationship between Raialo and Aravallis. Extensive work by Naha and his co-workers (summarized in Naha and Mohanty, 1990) has shown that both the Aravalli and the Raialo rocks participated in large-scale folding of two generations, i.e., westtrending isoclinal reclined folds are refolded into upright folds on $\mathrm{N}$ - to NE-striking axial planes. The first set of sub-horizontal conjugate $\mathrm{AF}_{3}$ folds) in thinly layered/schistose rocks is accompanied by isoclinal $\mathrm{AF}_{2}$ folds. The conjugate $\mathrm{AF}_{4}$ folds show vertical axial planes with NNW-SSE, and E-W strikes. Determination of the orientation of the principal stress axes from the late phase conjugate folds indicates that the $\mathrm{AF}_{3}$ folds got induced by the maximum vertical compression, and the $\mathrm{AF}_{3}$ resulted from a NE-SW horizontal maximum compression parallel to the schistosity. This analysis, therefore show, the rocks classified as Raialo rocks in this area do not have any independent structural or stratigraphic entity.

The SCAT also has some exciting features which include (i) a set of listric faulting induced inversion of dips in the basal areniteconglomerate unit (Roy, 1988) (ii) intense mylonitization in the uppermost parts of the BGC basement due to strike-slip movements along shear zones, although steep plunging lineations indicate involvement of a vertical component along ductile shear zones (Sinharoy,1989) and (iii) a prominent Banas Dislocation Zone (BDZ) identified by Sinha Roy et al. (1993). This zone separates the Aravalli fold belt and the BGC and therefore was interpreted to represent a reactivated boundary fault of the Aravalli rift basin.

Geochronology: $\mathrm{Pb}-\mathrm{Pb}$ age data for the mineralized carbonates of Rajpur-Dariba and Rampura-Agucah Belt (Fig-2) suggest an ore formation event at $\sim 1800 \mathrm{Ma}$. In contemporary literature, it is invariably noted that the sedimentation in SCAT commenced between 2.1 and $1.9 \mathrm{Ga}$ on the premise that the Rb-Sr isochron of the Darwal Granite (Choudhary et al., 1984) in the vicinity of Nathdwara belong to this age bracket. Later studies have shown that this granite is intrusive into the rocks of the BGC and not Aravallis. Hence, placing the base of Aravallis at $>1.9$ Ga has been found untenable (also see Deb and Thorpe, 2004). In this context, it is pertinent to point out that Ahmad et al. (2008) presented a series of whole-rock Sm-Nd model ages of 2.3 and $1.8 \mathrm{Ga}$ for mafic volcanic rocks overlying the basement gneisses, referred these volcanics to the last phase of basement rifting and noted geochemical similarities with the volcanics found interlayered with rocks of the BGC.

$\mathrm{An}$ array of $\mathrm{Pb}-\mathrm{Pb}$ model ages for the lower part of Aravalli succession suggests ages in the range of 1.8-1.7 Ga (Deb et al., 1989; Deb and Thorpe, 2004). Russell (1993) determined the $\mathrm{Pb}-\mathrm{Pb}$ isochron age for the stromatolitic phosphatic dolomite of Matoon and Kanpur deposits as $1712 \pm 34 \mathrm{Ma}$, which shows compatibility with the zircon age determined by McKenzie et al. (2013). The Pb-Pb age (Sarangi et al., 2006) of carbonates from the Ghasiar area (Rama-Nathdwara sector) with heavy carbon isotopic value yielded an age of $1921 \pm 67$ Ma. This $\sim 200$ Ma difference between the ages of the two carbonates units supports the contention that the carbonate rocks with heavy carbon isotopes are older than the stromatolitic phosphatic dolomites of Udaipur region (discussed above).

Recently, detrital zircon ages (Fig. 2) obtained by Wang et al. (2018) are consistent with the nature of the rock type, but their stratigraphic interpretation is debatable. These authors have followed the stratigraphy advocated by Roy and Jakhar (2002), which has seen many versions in recent years (Purohit et al., 2015). In this zircon analysis, the age of $\sim 2560$ Ma from the thin interlayered clastics with basic volcanics, perched on top of the BGC rocks, show ages similar to the rocks of the basement (BGC). As discussed above, these rock units represent the last phase of the rifting of the BGC and therefore does not form the basal unit of the Aravalli succession. The 1880 Ma age assigned to the Middle Aravallis of Roy and Jhakhar (2002) is the age of the thin veneer of arenite associated with the metavolcanics on top of the BGC and mistakenly assigned to the gryawacke-phyllite assemblage of the Udaipur valley. The $1780 \mathrm{Ma}$ age assigned to the greywacke-quartzite-phyllite assemblage of Udaipur Formation appears consistent with the age peak at $1760 \mathrm{Ma}$ as proposed by McKenzie et al. (2013).

The metavolcanics and quartzite association occurring at the culminating rift phase of the BGC (see above) contains a range of Archean zircon grains with only a single concordant zircon younger than $2.5 \mathrm{Ga}$ (Fig. 2). These older zircons appear to have been derived directly from proximal BGC. Zircon from the arkosic quartzite, occurring a few meters below the stromatolitic phosphatic dolomite near Jhamarkotra Mines, yielded a large population of 1.9-1.7 Ga detrital zircon ( 1772 Ma age peak) and the youngest single grain yielded age of $1762 \pm 9$ Ma. The Girwa valley greywacke-phyllite assemblage (Absar and Sreenivas, 2015), overlying the stromatolitic carbonates, contain a broad population of 1.8-1.6 Ga detrital zircon with abundant $\sim 2.5 \mathrm{Ga}$ grains and a single youngest zircon with ${ }^{207} \mathrm{~Pb} /$ ${ }^{206} \mathrm{~Pb}$ age of $1576 \pm 7 \mathrm{Ma}$. The presence of a large population of 1.91.7 Ga zircon grains in the dominant phosphorite-dolomite rocks with clastic intervals nullifies the assertions of 2.2-2.0 Ga depositional ages for this formation, including all overlying strata of the Aravalli Supergroup. The detrital zircon data presented by McKenzie et al. (2013) found support from $\sim 1.7 \mathrm{Ga} \mathrm{Pb}-\mathrm{Pb}$ model ages for syngenetic ore deposits associated with these carbonate formations, which provide tentative minimum depositional age (Deb and Thorpe, 2004). It is, therefore, safe to interpret the depositional age of the dolomitephosphorite of the Matoon/ Jhamarkotra Formation, overlying the arkose-quartzite of Debari Group as $\sim 1.7 \mathrm{Ga}$. This age estimate further supports the finding that Matoon/ Jhamarkotra Formation lacks younger $\sim 1.6 \mathrm{Ga}$ zircon grains. The $1.6 \mathrm{Ga}$ zircons are present in the overlying greywacke-shale of Udaipur Group and are consistent with a younger depositional age for this unit.

Inferences from Phosphorite: The $\sim 1.7$ Ga maximum depositional age for the basal Aravalli quartzites negates the interpretation that this unit was deposited during a 2.0 Ga global phosphogenic event following the Great Oxidation Event (Papineau et al., 2009, 2013; Papineau, 2010). Phosphatic stromatolites widely distributed in $\sim 1.6$ 
Ga late Paleoproterozoic (Statherian) rocks of the Vindhyans, Lesser Himalaya (Gangolihat Dolomite: Calymmian to Ectasian) and Cuddapah Supergroup (Statherian to Calymmian) suggest they are (i) restricted to the stromatolitic bioherms, with the phosphatic intraclasts in the inter-columnar spaces and (ii) the phosphatic crusts around the individual columns pinching-out along discrete intervals of the bioherms. The phosphate-bearing branching, columnar stromatolitic bioherms of the Udaipur region are several meters in stratigraphic thickness (Banerjee, 1971a). These specific similarities suggest a common mode of phosphogenesis and similarities of mineralization, and their ages suggest there may have been similar over-arching controls on carbonate fluorapatite precipitation in the Himalayan and other Proterozoic basins of India (McKenzie et al., 2011).

\section{Delhi Mobile Belt}

\section{Diachronous evolution of the Delhi Mobile Belt}

Hacket $(1877)$ and Heron $(1917,1953)$ contended that the rocks from NE Rajasthan to Gujarat, deposited in spatially disconnected basins (Fig. 1), represent a single contemporaneous lithostratigraphic domain clubbed under the "Delhi System." After a long status quo, recognition of two chronologically distinct intrusive magmatic events separated in time by at least 800 Ma (Fig.4; Choudhury et al., 1984) intruding into the northern and southern basins was taken to suggest (Gupta et al 1980; Sinha Roy et al 1984; GSI, 2011) that the Delhi basins diachronously evolved in (i) northeastern Rajasthan with multidepocenters referred to as North Delhi Fold Belt (NDFB) and (ii) all along the central and western edifice of the Aravalli Mountain Range (Main Delhi Synclinorium of Heron, 1953) representing younger basin referred to as South Delhi Fold Belt (SDFB). Sinha Roy (1988) proposed that the ENE-WSW to E-W trending Jaipur-Dausa-Alwar transcurrent fault as the contact between the NDFB and the SDFB. Gupta et al. (1998) and Gupta and Bose (2000) have indicated the occurrence of rocks of migmatitic basement gneissic complex in intervening areas between NDFB and SDFB and even in the interbasinal areas of the NDFB. As in the case of Aravallis, the debate on the contemporaneity of Delhi rocks distributed in two spatially disconnected basins ensued on the presumed similarity of structural elements and metamorphic impress (Roy, 1988; Singh, 1988; Sharma, 1988). Despite assertions on a regional basis, one-to-one structural correlation of the type sections between the NDFB and the SDFB has not been demonstrated as yet, albeit the structural elements of Delhi rocks of Central and northeast Rajasthan together were found to have structural discordance with the Pre-Delhis (migmatised Aravallis, Naha, et al. 1984). Biswal (1988) reported the contrast in the structural elements between the NDFB and SDFB. He suggested that $\mathrm{DF}_{4}$ folds are more extensive and therefore controlled the map pattern in the SDFB. The $\mathrm{DF}_{5}$ folds are seen only in the SDFB. The recent age data from these basins reflect the time lag between the two depositional events. U-Pb ages of zircon from NDFB and SDFB (Wang et al. 2017) helped to infer a predominant Palaeoproterozoic source for the detritus of the NDFB units thereby limiting the maximum depositional age to ca. 1720 Ma for the uppermost Ajabgarh Group. It also explained the reason for widespread Mesoproterozoic detritus in the South Delhi sedimentary units and also constrained the initial sedimentation of these units to younger than 1055 Ma. Therefore diverse age signatures of provenance for the northeastern and southwestern segments of the Delhi Supergroup preclude any temporal correlation between the two domains. The two belts with distinct depositional ages may have formed either in discrete subbasins or altogether independent basins (Wang et al. 2017). On the other hand, a pervasive, late metamorphic event uniformly affected the two basins (see below).

North Delhi Fold Belt (NDFB): Heron (1953) classified the rocks of Delhi System into carbonate-arenite dominated Raialo series, more or less pure arenite dominated Alwar series, and pelite-calcareous sediments and metabasic dominated Ajabgarh series. Gupta et al. (1997) used the lithostratigraphic term Delhi Supergroup for the Delhi System and divided it into Raialo, Alwar and Ajabgarh groups. Three independent sediment repositories constitute the NDFB. These are (i) Khetri, (ii) Alwar, and (iii) Lalsot-Bayana (Fig. 1G). These are affected by inter-basinal faults and prolific intrabasinal synsedimentary dislocation zones. Sinha-Roy (1988) contended that the NDFB prograded from east (Bayana) through Alwar to the west (Khetri) as pull-apart basins.

The $80 \mathrm{~km}$ long Khetri basin, well known for the copper mineralization, occurs towards the western extremity of the NDFB, near the Sikar and Jhunjunu areas (Fig.1). An E-W trending Kantli Fault in the middle divides the basin into the North Khetri Belt (NKB) and South Khetri Belt (SKB basins). Khetri and Shyamgarh groups are represented by the rocks of Alwar and Ajabgarh groups in NKB and SKB, respectively. Quartzites, para-amphibolites, metagreywacke, and meta-pelites occur in the Khetri Group, whereas the Shyamgarh Group consists of meta-pelites, felsic volcanics, carbon phyllite, quartzite/conglomerates, carbonates, BIF and metagreywackes. Granites (Gotro, and Jasrapura granites in NKB and Paniaas, Chapoli, Udiapurwati, Saladipura and Seoli granites in SKB) and dolerites occur as intrusive rocks. Increased intensity of deformation and metamorphism and distinct mineralization styles has prompted many workers to suggest that the Khetri basin has different tectonometamorphic features compared to other basins of the NDFB (Roy Chowdhury and Dasgupta,1964; Mehdi et al., 2015). An essential aspect of the belt is the ubiquitous presence of albite bodies in a narrow zone termed as Albitite Line (Ray, 1990). Recently, Kaur et al. (2018) studied the petrogenetic and tectono-metallogenic aspects in detail. Well developed Raialo carbonates near Dogeta and Makrana areas with sandstone occurs interspersed with bimodal volcanics rocks and represent tectonically uplifted basin (Dausa uplift; Singh, 1988). The easternmost Lalsot-Bayana Basin near Bharatpur (Fig. 1G) exposes the Raialo sequence of quartzite and well-sorted conglomerate overlain by basic volcanics (Jahaj-Govindpur volcanic, tholeiitic to high-K basalts). In both the basins quartzite of Alwar Group is overlain by the argillaceous Ajabgarh Group. Granitic bodies exposed at Bairat, Ajitgarh, Barodia, and Harsora are intrusives in the sedimentary succession. Albitites, a product of polyphase metasomatism, are omnipresent in this region.

Delhi Rocks of Ajmer-Sambhar Lake Sector: Between the NDFB and SDFB sporadic rock outcrops are exposed in the Ajmer and Sambhar Lake region t (Fig.1A) whose stratigraphic correlatability has not been correctly established(Fareeduddin et al., 1995). These rocks were assigned to (i) the Pre-Aravalli gneisses (through granitegneiss inlier in the Bearwar area); (ii) Aravalli sequence (like that of Sambhar Lake); (iii) parts of Delhi Supergroup and (iv) post-Delhi magmatic rock sequence (as in Ajesar, west of Ajmer). Several new 
interpretations are now available. Gupta and Bose (1995) did not find any similarity with the rocks of e Delhi Supergroup while Bose (1989) recorded structural continuity of the Anasagar granite-gneiss with the presumed Pre-Delhi inlier (Heron, 1953) near Beawar. The asymmetrical $\mathrm{F}_{2}$ folds in this belt show alternate flat and steep, locally overturned limbs with consistent easterly vergence (Mukhopadhaya et al., 2000), which are not seen in the SDFB (Gupta et al., 1995). Chattopadhyay et al. (2012) identified thrusts associated with the easterly-vergent $D_{2}$ folds having a ramp-flat geometry that is refolded by coaxial $D_{3}$ folds and reflect peak metamorphism (5.7 $\pm 1.5 \mathrm{kbar}$ and temperature of $560^{\circ} \mathrm{C} \pm 50^{\circ} \mathrm{C}$ ) in this area; these structures are characteristically different from the Delhi rocks of the SDFB (Gupta et al., 1995). Folds of these two areas are not contemporaneous, as evident from two sets of synorogenic granites of widely different ages ( $1600 \mathrm{Ma}$ in the Ajmer area and $850 \mathrm{Ma}$ in the SDFB: Choudhury et al., 1984). Mukhopadhaya et al. (2000) concluded that intrusion of the Anasagar granitoid-gneiss was pre- $\mathrm{F}_{2}$ (and late-tectonic with $\mathrm{F}_{1}$ ) and the $\mathrm{U}-\mathrm{Pb}$ zircon dating suggests a crystallization age of $1849 \pm 8$ Ma. Gupta and Bose (1995) also recorded an intense polyphase in situ migmatisation in the Anasagar area. Deb and Thorpe, (2004) obtained an age of $1745 \mathrm{Ma}$ for the Sedex type Pb-Zn mineralization (in Kayar, Ghugra, Lohagal areas) and Mckenzie et al. (2013), based on the detrital zircon age data, asserted that the zircon ages from quartzites of the SDFB differ sharply from the Alwar Group of rocks in the NDFB. Fareeduddin et al. (1995) differentiated these rocks as a distinct Ajmer Group occurring between the Aravalli and Delhi Supergroups.

South Delhi Fold Belt: Heron (1953) conceived the Delhi rocks of SDFB as part of a 'synclinorium' (the southeastern and northwestern synclines) with a median anticline in the center that exposes basement rocks. He also divided the rocks of this region of the SDFB into Alwar and Ajabgarh Series. In a significant deviation from the general stratigraphic concept, Sen (1980) proposed that the Delhi rocks between Ajmer to Pindwara in the south are distributed in three longitudinal basins viz Bhim, Rajgarh, and Barotiya with apparent age polarity towards west. This composite unit, according to him, is overlain in the west by a younger sequence. Retaining the classification of Heron and following the idea of a westward polarity Gupta et al. (1997) identified Gogunda Group and Kumbhalgarh Group and correlated them with the Alwar and Ajabgarh Groups, respectively.

In a basin where all the lithostratigraphic domains are intensely tectonised and telescoped one into another, a simplistic approach towards its classification is, perhaps, not valid. Gupta et al. (1995), following Sen (1988), emphasised on hierarchy of structural elements and relative structural discordances in Ajmer and Gogunda areas and suggested that (i) the Delhi Supergroup of rock in these basins are surrounded by pre-Delhi gneisses and schists on either side and (ii) the central part of the Aravalli range, near Beawar, a structural inlier of pre-Delhi rocks bisects the Delhi Supergroup into two sub-basins, the western Gogunda-Barotiya-Sendra basin, and the eastern RajgarhBhim-Ras basin. These observations allowed them to classify the Delhi rocks here into (Fig.1 and Fig.4), Gogunda, Barotiya, Sendra, RajgarhBhim-Ras groups . In fact, the latter three (Brotiya, Sendra, RajgarhBhim-Ras groups) represents the Kumbhalgarh Group of Gupta et al (1997).

Gupta et al. (1997) and Sinha Roy (1988) considered the tectonised mafic-ultramafic volcanic rocks (with gabbroic bands) occurring as discontinuous lenses in Barotiya-Sendra groups as ophiolite strips (Phulad ophiolite Belt) that show geochemical affinity to the modern ophiolite suites (Khan et al. 2005). Several isolated bodies of I-type granites (Sendra granites) in Sendra-Barotiya groups
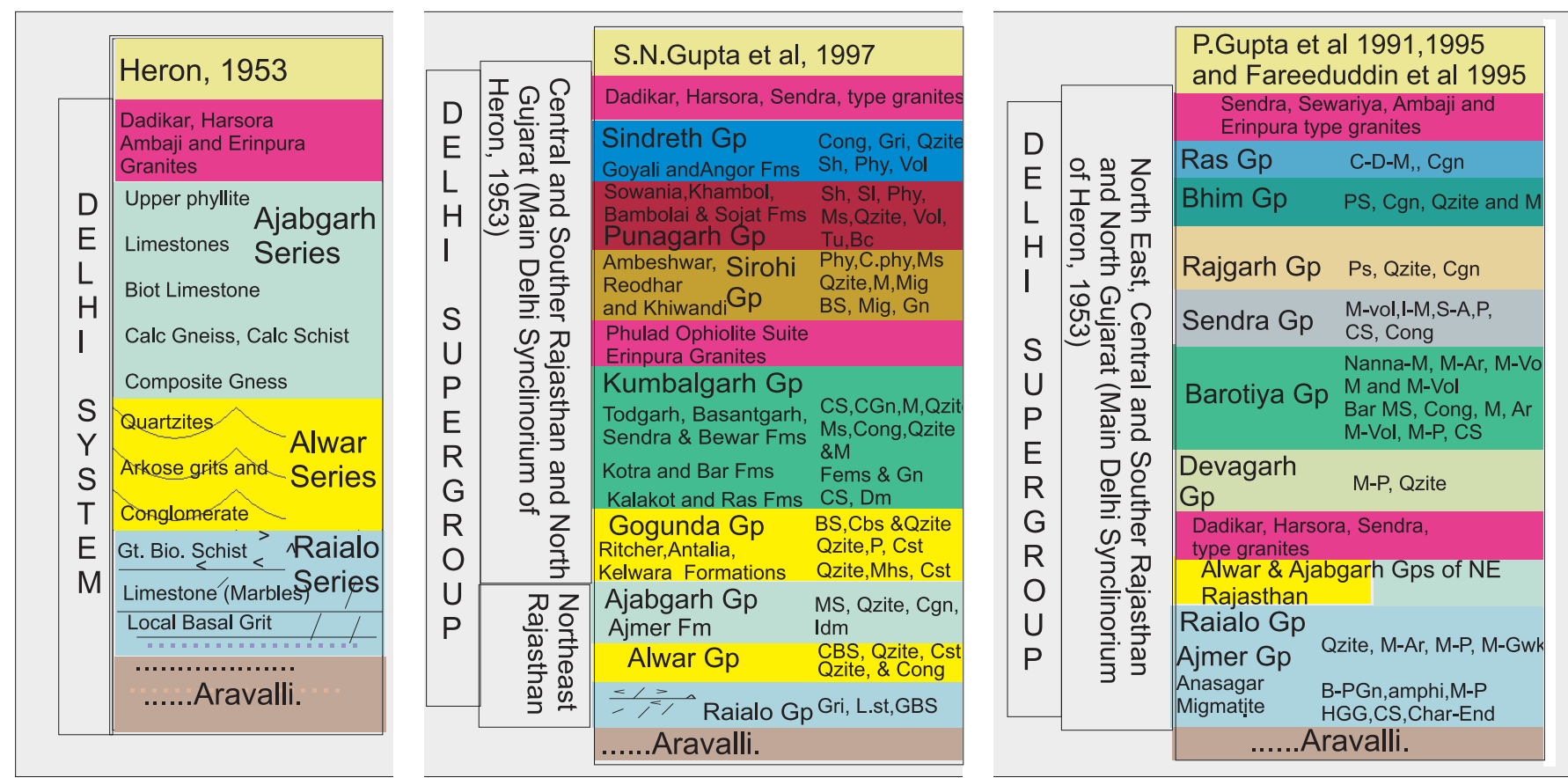

Explanations for abbreviations used: Bc-Bedded Chert, B-PGn- biotite bearing Para-gneiss, Bs-Biotite Schist, Cbs-Cal biot schist, C-D-M-Calcitic dolomitic Marble, C.Phy-Carbon phyllite, CGn-Calc Gneiss, Char- Charnockite,Cong-Conglomerate, Cs-Calc Schist, Cst-Calc silicate, Dm-Dolomitic marble, End-Enderbites, Fems Feldspathic, mica schist; Gn-Gneiss, Gri-Grit,HGG-High grade granulites, Idm-Impure dolomitic marble; Lst -Limestone; M-Marble, M-Ar-Meta Arkose, M-GWk-Meta Greywake, Mhs- mica hornblende schist; M-P-Meta pelite,Mig-Migmatite, Ms-Mica schist, Phy-phyllite,Qaite-Quartzite,Sh-Shale,SI-Slate,Tu-Tuff,Vol-Volcanics

Figure 4: Stratigaphic Schemes proposed for the Delhi Supergroup. 
and tungsten bearing S-type granite (Sewariya, Degana, Balda, etc.) intrude along the western margin of the SDFB. The simplified stratigraphic scheme proposes in this contribution is shown in Figure-1.

\section{Structure and metamorphism}

North Delhi Fold Belt: Four phases of folding (NNE-SSW trending, intensely attenuated coaxially folded doubly plunging antiforms and synforms, profuse shearing and E-W trending open folds with coeval local faults) characterize the Khetri rocks (Roy Chowdhury and Dasgupta,1964). Structural studies by Ray (1974) in South Khetri Belt revealed that out of the three phases of folds, the first twofold sets are the result of the same deformation. The first generations of folds, formed by the flexural mechanism through NW-SE directed horizontal compression, are associated with a strong axial planar foliation. Superposed second folds are coaxial with the first folds and are associated with shearing. The cross folds represent the third phase formed by NE-SW directed compressive strain on a regional scale. A similar study in the NKB by Naha et al. (1988) confirmed the observations made by Ray (1974). The differences between the two studies, however, lie in recognition of the first fold as a result of simple shear and its variance from the second folds formed by pure shear movements, as suggested by Naha et al. (1988). These authors also recognized a set of folds with the subhorizontal axial plane as the third fold, resulting from the gravitational load that formed before the regional cross folding episode. In Alwar and Lalsot-Bayana basins, polyphase folds resulted in intricate outcrop patterns with abundant structural duplication. The early folds are tight to isoclinal, upright to moderately plunging NNE-SSW trending antiforms and synforms, which were subsequently refolded on NW-SE and ENE-WSW axial planes, resulting in axial culminations and depressions.

The NKB and SKB of the Khetri Copper Belt represent two metamorphic zones, i.e., andalusite-sillimanite and kyanite-sillimanite (Lal and Shukla, 1975; Sharma, 1988). Bhola (1989) studied metapelite rocks of the Bayal area in Alwar basin and estimated PT in the range of $540{ }^{\circ} \mathrm{C}-600^{\circ} \mathrm{C}$ and 4 to $5 \mathrm{~Kb}$ pressure. Pant et al. (2000) recognized two sets of assemblages in sub-calcic amphibole bearing rocks from Bayal area wherein cordierite and gedrite have developed by consumption of chlorite and quartz and inferred the temperature of $\sim 540^{\circ} \mathrm{C}$ at pressure $>4 \mathrm{~Kb}$. Kundu et al. (2004) identified peak metamorphic assemblage in the metapelites and metabasic rocks and estimated $550^{\circ}$ to $640^{\circ} \mathrm{C}$ temperature and 5 to 7 $\mathrm{Kb}$ pressure. In stark contrast, Mehdi et al. (2015) reported that the Lalsot-Bayana basin has sub-green schist facies mineral assemblages $\left(\sim 300^{\circ} \mathrm{C}\right)$. These studies suggest either (i) there is a strong westward increase in grade of metamorphism or (ii) tectono-metamorphic development of Lalsot-Bayana basin postdates its other two western counterparts.

Ajmer Sambhar Lake Sector: As mentioned before, Gupta and Bose (1995) recorded that tectonic structures in this area are distinctly different from the rocks of the SDFB. Mukhopadhyay et al. (2000) indicated that (a) both the Anasagar granite-gneiss and the supracrustal rocks are involved in polyphase deformation; (b) $\mathrm{F}_{1}$ isoclinal folds are present only on minor scale in the supracrustal rocks; (c) $F_{2}$ major and minor folding have affected both the gneiss and the supracrustal rocks and that these are asymmetrical folds with alternate flat and steep, locally overturned, limbs with consistent easterly vergence; (d) $F_{3}$ folds are upright and coaxial with $F_{2}$; (e) $F_{4}$ puckers and large scale warps have E-W to ESE-WNW sub-vertical axial planes; and (f) the gneisses exposed in the core of an $F_{3}$ arch on the flat limb of a major $\mathrm{F}_{2}$ antiform got the axial trace bent by an $\mathrm{F}_{4}$ fold. Chattopadhyay et al. (2012) reported thrusts associated with the easterly-verging $D_{2}$ folds, which show a ramp-flat geometry and are refolded coaxially during $D_{3}$ folding. Distinct metamorphic zonations are discernible from east to west. These are the staurolite-kyanite zone in the east and sillimanite-muscovite zone in the center (Fareeduddin et al.,1995). Chattopadhyay et al., (2012) report peak metamorphic conditions of $5.7 \pm 1.5 \mathrm{kbar}$ and $560^{\circ} \mathrm{C} \pm 50^{\circ} \mathrm{C}$, whereas Bose et al., (2017) recorded an increase in the metamorphic conditions $(7.7 \pm 0.11 \mathrm{~kb}$ and $592 \pm 12^{\circ} \mathrm{C}$ ) in metapelites towards eastern margins near AjmerShrinagar section.

South Delhi Fold Belt: Gupta et al. (1995) identified four phases of folding on mesoscopic scale reflected as (i) rootless, highly flattened, isoclinal $\mathrm{F}_{1}$ folds with variable geometry and attendant pervasive axial planar schistosity $\left(\mathrm{S}_{1}\right)$ and lineations $\left(\mathrm{L}_{1}\right)$; (ii) $\mathrm{F}_{2}$ folds, recorded in different sectors of SDFB are large reclined to antiformal synclinal folds. Congruous mesoscopic upright to steeply inclined, vertical to reclined folds are seen in the Giri area. In the Kaleb Kalan area large reclined sidewise closing folds are exposed. The flattened folds with a subrounded hinge, occasionally cylindrical are associated with a strong axial planar cleavage, which has often transposed the earlier axial planar structure. This area has open to tight $F_{3}$ folds with occasional development of axial planar fabric and an intersection lineation along with cross-warps $\mathrm{F}_{4}$ folds. The complicated dominant structural pattern, resulting from $2^{\text {nd }}$ and $3^{\text {rd }}$ phases of folding and extensive shearing controls the map architecture of the SDFB rocks.

The Abu-Balaram-Kui-Surpagla-Kengora granulites: Desai et al. (1978) recorded granulites from the southwestern extremity of the ADMB, which occur as tectonically bounded lensoidal bodies within the low-grade rocks of the Ambaji basin of SDFB (Fig.1D). The granulites comprise metapelite, calc-silicates/gneiss, basic granulites, and charnockite. Srikarni et al. (2004) reported sapphirine-bearing assemblages in the pelitic granulites. Biswal et al. (1998) included these as metamorphosed Delhi rocks and estimated $P$-T conditions of granulite facies metamorphism at $\sim 8 \mathrm{kbar}, 900^{\circ} \mathrm{C}$. Singh et al. (2010) reported spinel-cordierite-garnet-sillimanite-quartz assemblage that has peak thermo-barometric condition set at $\geq 850^{\circ} \mathrm{C}$ and $5.5-6.8 \mathrm{~kb}$.

\section{Geochronological Studies}

North Delhi Fold Belt: The geochronological studies for NDFB (for references, please see Figure-4) is summarized below:

- Detrital zircon from the Alwar Quartzite has yielded an age of $3671 \pm 15 \mathrm{Ma}$. This, oldest zircon hitherto unreported from northwestern India, represents the basement which may have contributed to the sediment influx to the North Delhi basin. None of these basement phases are seen in rocky outcrops of this region.

- Detrital zircon from the Raialos show age range between 2510 Ma and 2309 Ma.

- Youngest detrital zircon from the Alwar Quartzites is dated

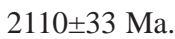

- The initial comprehensive Rb-Sr dating indicated a wide range of ages between $1340 \mathrm{Ma}$ and $1850 \mathrm{Ma}$ (with relatively larger 
error-chron) for the granitic plutons of the NDFB (Choudhury et al. 1984) Revised and more precise zircon age data indicate 1700 Ga age (Dadikar and Harsora granites, Kaur et al.) for these plutons.

Significantly robust and precise geochronological data, albeit, some apparent contradictions (ages from the same region by different working groups contradict) place several constraints on the suggesting scientifically correct evolutionary models for the NDFB:

- The identification of $3671 \pm 15$ Ma zircons age add a new dimension to the understanding of un-recognized Eoarchean to Neoarchean basement segments in this region;

- The early field studies considered various granite plutons of NDFB as intrusive bodies. In marked contrast, Biju Shekhar et al. (2003) found them to represent 1800-1700 Ma old basement to the sedimentary pile. This latter interpretation is untenable since the youngest zircon from the Alwar Quartzites is $2110 \pm 33$ Ma constraining the sedimentation age in the basin.

- The Delhi metamorphism dated by Pant et al. (2008) suggests $\sim 950$ Ma time bracket. Kaur et al. (2018) recognized four different ages of metamorphism (between 1.85 and $980 \mathrm{Ma}$ and one phase of metasomatism at $~ 900-850$ based on zircon age data. Sharma (1988) after years of study in this region by) does not subscribe to the idea of four metamorphic episodes.

Ajmer Sambhar Lake Sector: In the Ajmer area, U-Pb dates of zircon indicate that the precursor granite of the Anasagar migmatite within Ajmer town got emplaced within the supracrustal unit during an early folding event at approximately $1.85 \mathrm{Ga}$. On the other hand, the in situ monazite dating of a staurolite schist sample from the AjmerShrinagar section yielded a pooled age of $980 \pm 22$ Ma, which is assumed to be the age of the peak metamorphism (Bose et al., 2017). The ${ }^{206} \mathrm{~Pb} /{ }^{207} \mathrm{~Pb}$ data on 10 zircon grains from the migmatite sample (for individual references please refer Figure-4) yielded ages of 1695.7 Ma to 2258.1 Ma suggesting (a) existence of Paleo-Mesoproterozoic provenance for the precursor sedimentary basin and (b) the youngest age of 1700 Ma constraining the youngest age of this basin which is arguably contemporaneous to the Aravallis (Fareeduddin and Kroner, 1998).

South Delhi Fold Belt: The geochronological studies for SDFB (please see Figure-2 for dates and their respective references) could be summarized as follows:

- The age of accumulation of volcanic (1000-1100 Ma) sediments (1240 to $860 \mathrm{Ma}$ ) ranges between $1240-860 \mathrm{Ma}$, which must be the age of basin infill. The age of massive sulfide ores in bimodal volcanics of Deri area dated at 1100 Ma falls in the same age bracket

- The Rb-Sr age of 955 Ma to 740 Ma for the post-Delhi PaliSendra-Erinpura Magmatic Cycle is now well constrained with more precise zircon geochronology that also reflects the similar age bracket of $968 \pm 1.2$ Ma to $800 \pm 2$ Ma. Tiwari and Biswal (2019) observed that Sendra Granite ( 980 Ma) and Sewariya Granite ( $860 \mathrm{Ma}$ ) got deformed by $\mathrm{D}_{1}$ deformation. Hence Delhi deformation cannot be older than 860 Ma.

- Ambaji-Deri sector exhibits two distinct ages: The zircons from northern and southern parts reflect uniformly identical zircons of $\sim 987 \mathrm{Ma}$, whereas the zircon and monazite in
Siyawa granite exhibit ages of $836 \mathrm{Ma}$ and $826 \mathrm{Ma}$ respectively.

- In the Ambaji sector, the monazites from Ambaji granulites yielded distinct ages in the range of $875857 \mathrm{Ma}, 834778$ $\mathrm{Ma}$, and $764650 \mathrm{Ma}$ corresponding to respective deformational episodes, indicating that the South Delhi orogeny spanned between 875 and $650 \mathrm{Ma}$.

- In the Mt Abu-Sirohi sector, Mt Abu granite reflects the ages of $764 \pm 3$ Ma to $779 \pm 16$. The granulite facies metamorphism and their exhumation are dated $\sim 800$ to $860 \mathrm{Ma}$ and $\sim 800$ to 760 Ma, respectively.

Sirohi-Sindreth basins - postulation of a younger Neoproterozoic Orogeny: The supracrustals of Sirohi and Sindreth groups represents youngest sequences of Delhi Supergroup (Fig-1). Arora et al. (2017) observed that the Sirohi metasediments were (i) deposited over a basement of $892 \pm 10$ Ma old Erinpura granites (ii) metamorphosed under low to medium grade metamorphism at $822 \pm 29$ Ma and (iii) the formational trends and the pervasive fabric in the metasediments are in NW-SE direction which corroborates well with the aeromagnetic signatures of this terrain (Fig. 1C: Gouda et al. 2015). The latter indicates the presence of an NW-SE trend that orthogonally impinged the NE-SW trend of the South Delhi Fold. Since Sirohi sediments were deposited over a post-Delhi Erinpura basement of >890 Ma with structural discordance with Delhi structural fabric, Arora et al. (ibid) interpreted the existence of a Neoproterozoic fold belt which deformed at $822 \mathrm{Ma}$. Alternatively, it may be argued (S.K. Ray, Pers.Comm.) that this NW-SE trend need not represent the trends of Post-Delhi orogeny, instead, it reflects the pattern of the youngest generation of folds. Such trends are consistently observed in many other parts of the Delhi fold belts (Khetri belt of NDFB and the Todgarh areas in SDFB). In Sirohi area, the NW-SE trend appears to be dominant and controlled the map pattern. This map pattern is observed because of (i) open nature of the early folds, on which these are superposed, or (ii) gentler axial surface dip of the early folds (compared to the axial surface of the early folds of Khetri Copper Belt), or (iii) both.

\section{Discussion}

\section{Aravalli Craton - the Archean Evolutionary history}

The Aravalli region reflects the existence of 3.7 to 3.5 Ga old Eoto Paleoarchean proto-continental nuclei in northwest India, as evident from the detrital zircons dates in the Aravalli and Delhi metasediments. Notwithstanding the early $\mathrm{Sm} / \mathrm{Nd}$ date of $3.5 \mathrm{Ga}$ for the host gneisses and amphibolites (MacDougal et al., 1983), it is generally presumed that this proto-continental nucleus is not exposed anywhere although the presence of the older zircon in the sediments support the idea of the existence of a protocontinent in the Aravalli hinterland. In contrast, the Mesoarchean crust, well exposed in the region was affected by subsequent cratonisation events. The bulk of the continental accretion appears to have occurred during Neoarchaen time that spasmodically continued during the Proterozoic. The net result of such a protracted cratonisation event is the eventual creation of the polyphase granite gneiss terrains representing the Banded Gneissic Complex. The suggested names of the Mangalwar Gneiss or Mewar Gneiss for the BGC do not stand ratification as per the international codes of 
stratigraphy, and therefore it is recommended that the lithodemic nomenclature of the Banded Gneissic Complex should be retained. The recent geochrnological studies have, by and large, ratified the two broad field-based sub-divisions of the BGC into BGC-I and BGCII. While BGC-1 is a valid entity, doubts have been expressed regarding BGC-II. The BGC-II hosts many tectonised lenses of granulite-facies rocks that occur within gneisses showing amphibolite facies metamorphism. These represent the crustal thickening events during early Mesoproterozoic and also during the Neoproterozoic. In analogy with other Precambrian terrains, greenstone components in the Aravalli Craton are postulated, although, the tell-tale evidence for the authentic greenstone belts, so common in different Precambrian terranes of the world, is missing from this belt. Recent robust geochronological studies conclude that the region was affected by a widespread $~ 2.5$ Ga old end-Neoarchean craton stabilization event.

\section{Proterozoic Mobile Belts}

Evolution of the Stratigraphic Concepts in ADMB: A century-old concept of the Aravalli mountain range with 'Aravalli and Delhi systems overlying the BGC' changed with time and the current idea of 'Aravalli-Delhi Mobile Belt attached to the Aravalli Craton' evolved in tandem with the contemporary philosophies in the geological sciences. Thi complex $\sim 2$ billion year Craton-Mobile Belt story can not be treated in simplistic manner. Over the years, the supracrustal belts are designated as the formal status of Supergroup and Group with distinctive internal stratigraphic order. Geological studies between 1970 and 1990 emphasized on primary and secondary structural features to build up stratigraphy. Several dissenting opinions amongst the major working groups came into print and a plethora of proposed stratigraphic schemes continued to confuse new researchers in the field.

In spite of the differences of opinion a broad picture has emerged which reiterates: (a) Aravalli and Delhi represents two orogenic belts that evolved one after the other with separation in space and time; (b) each of the Aravalli and Delhi basins developed in two or more independent tectonic domains but occur in physical contact with each other; (c) the terrain between Nathdwara-Bhilwara-Chittaurgarh, designated in this contribution as East Aravalli Terrain, comprised extremely flattened and attenuated strips and islands of deformed metasedimentary belts. These deeply shear-dissected lithologies defy a valid, formal, and acceptable internal hierarchical order as they occur amidst migmatised and granitized paragneisses. Some recent workers treat the metasedimentary belts as Aravallis and the migmatised gneisses as the BGC (Sinha-Roy, et al., 1993) while Roy and Jhakar (2002) consider the entire metasedimentary belt including the migmatised metasediments as Aravalli; (d) the NathdwaraUdaipur- Lunavada terrain designated as the West Aravalli terrain, has well preserved primary depositional features that facilitated interpretation of fairly well organized and structured stratigraphic order, albeit, a few debatable units which require rethinking. (e) the most conspicuous feature of this Aravalli succession is the identification of two successive phases of sedimentation manifested in the shallow marine quartzite at the stratigraphic base, carbonateargillite sequence in the middle,and greywacke-argillite dominated deep-sea sediments at the top; (f) deposition of carbonate rocks with anomalous carbon isotopes in two separate basins of different ages (g) the Delhi depositional regime in two disconnected basins of northeast Rajasthan (NDFB) and the main edifice of Aravalli mountain range (SDFB). (h) the stratigraphic order proposed by Heron (1953) for NDFB is largely retained (albeit with local revisions), its applicability to the SDFB has been questioned based on identification of polyphase inter-sub-basinal structural discordances; (i) an independent identity for the litho-packages that occur in the transition areas of the NDFB and SDFB in Ajmer-Sambhar Lake sector and (j) a linear supracrustal belt with NW-SE trending principal structural fabric near Sirohi, orthogonal to the Delhi structures represent an activity younger than the Delhi orogeny although alternate hypothesis has been proposed.

The aforementioned assertions make us realize that the ADMB, considered earlier as 'rock series of two independent systems', actually represents a collage of several independent litho-tectonic domains. The accretionary processes were apparently independent of each other although their tectono-metamorphic evolution or orogenic development may not have been independent since thermal imprints are seen on the multiple accreted terrains.

ADMB Orogeny: Several decades of robust field studies led to the recognition that Aravalli and Delhi rocks have undergone polyphase deformation manifested in at least three regional folding phases with one additional phase that could be locally abundant at few places in either of the fold belts (Naha et al.,1984; Roy, 1988; Gupta et al., 1995). Structural studies conducted on critical sections of Delhi and Pre-Delhi rocks by Naha and his co-workers in early 1984 revealed a remarkable identity in the later phases of the deformational history of the pre-Delhi and Delhi rocks, with gravity-induced structures followed by conjugate folds due to longitudinal shortening (N-S in northeastern Rajasthan and NE-SW in central Rajasthan). The earlier stages of the structural history of the two groups are, however, significantly different. The E-W trending reclined folds of the first generation in the pre-Delhi rocks are absent in the Delhi rocks throughout Rajasthan. The NNE-SSW to NE-SW trending folds of the second generation in the pre-Delhi groups are upright, whereas these structures in the Delhi rocks are of two phases: recumbent folds, followed by coaxial upright folds. Evidence has been adduced to suggest that these differences in the earlier phases of the structural evolution of the two groups are due to an angular unconformity between the Delhi and the pre-Delhi rocks.

While synthesizing the structural framework of the ADMB region, Roy (1988, p.22), asserted that (i) temporally close $\mathrm{DF}_{1}-\mathrm{DF}_{2}$ folds, formed during Delhi orogeny are represented by $\mathrm{AF}_{2}$ folds of the Aravallis whereas $\mathrm{AF}_{1}$ folds are manifestation of the Aravalli orogeny; and (ii) the $\mathrm{DF}_{3}$ and $\mathrm{AF}_{3}$ folding cannot be tied up with the Delhi deformation. The additional late fold phases are seen superimposed on the early Delhi folds (Gupta et al., 1995; Biswal et al., 1988). The structural data, therefore, suggest an intense effect of the Aravalli and Delhi orogenies to generate the most prolific $\mathrm{AF}_{1}$ folds in the Aravallis and $\mathrm{AF}_{2}+\left(\mathrm{DF}_{1}+\mathrm{DF}_{2}\right)$ fold phases in the Aravali-Delhi rocks. The musings over the effects of another younger orogeny such as Sirohi orogeny (Arora et al., 2017) or Champaner orogeny (Roy, 1988,p.22), however, requires more detailed studies for confirmation.

Unraveling these orogenic episodes through syntectonic regional metamorphic recrystallization events generated conflicting views. Sharma (1988) construed that all pre-Aravalli rocks are polymetamorphic, but both Aravalli and Delhi rocks are monometamorphic, except for the later thermal imprints related to massive granite emplacement in Delhi fold belt. He, therefore, suggested that only two orogenies affected south-central Rajasthan, the pre-Aravalli 
and Delhi orogeny. According to Sharma (1988) the Aravalli rocks, sandwiched between the Delhis and the BGC, show low grade of metamorphism, whereas the overlying Delhis and the underlying BGC, being the youngest and oldest rock units respectively, show higher grades of regional metamorphism. Sharma (1988) further argued that unless the two belts are subjected only to one regional metamorphic event, it is difficult to account for the occurrence of Delhis with higher grade of metamorphism overriding the low-grade Aravallis. It is significant to note that relative ages of the fold belt in polymetamorphic terrains and the degree of metamorphism can not be directly correlated. It is pertinent to point out that while the low-grade metamorphic rocks of the South Central Aravalli Terrain were subjected to the above interpretation, the medium to high-grade polymetamorphites of the East Aravalli Terrain were ignored. The application to the latter may defy the simplistic approach of a single orogenic phase for the ADMB supracrustals.

Early phases of metamorphism in the ADMB have been conclusively demonstrated (Bhowmick et al., 2010), where the earlier $\mathrm{M}_{1}$ sillimanite-facies metamorphism and younger kyanite-facies HP metamorphic event caused re-heating and prograde burial of the $\mathrm{M}_{1}$ granulites. This suggested the entire stretch of ADMB domain experienced crustal thickening as part of the same collisional orogeny during Late Palaeoproterozoic (Stratherian) at ca 1.72 Ga. Another more pervasive and intense metamorphic recrystallization event recorded in ADMB (including underlying basement granitoids, gneisses, and granulites extending further east to Rampura-Agucha and Pur-Banera supracrustal belts) relates to the ca. 1.0 Ga collisional orogenic front (Bhowmik et al., 2018). Besides 1.0 Ga old clockwise metamorphic P-T paths from Sandmata metamorphic complex and Anasagar migmatites and Shrinagar metapelites near Ajmer, a metamorphic imprint of $\sim 1.0$ Ga was recorded in the rocks of the Alwar basin (Pandey et al., 2013). It is apparent that the ADMB and the BGC have exposed middle to lower crustal sections of the ca. 1.0 Ga orogen.

Further, Bhowmick et al. (2018) modeled the P-T array of these rocks coupled with CW P-T path constraints, to suggest that radiogenic heat production in a tectonically thickened continental collisional zone could be the dominant mechanism of middle to lower crustal heating in vast stretches of the ADMB at ca. $1.0 \mathrm{Ga}$. The inferences from the metamorphic studies are supported by the sub-surface geophysics (Mishra and Ravi Kumar, 2014) that indicates gravity high on ADMB with dipping crustal structures suggestive of the uplifted lower crust (density of $2.9 \mathrm{~g} / \mathrm{cm}^{3}$ ) with crustal thickening ( 45 km) in the central part. The IGRF corrected magnetic data (Gouda et al., 2015) suggest much widespread existence of magnetic bodies similar to those seen in the Sandmata region in the alluvial covered tracts of the north and northwestern parts of Rajasthan implying pervasive presence of 'Sandmata-like' metamorphic event, the implications of which need to be further explored. When viewed with this new data the report of occurrence of Sandmata-like successions in the trans-Aravalli region in the northwestern part of the ADMB near Pilwa-Chniwali areas gains much significance.

In view of the absence of additional report of ca. 1.4 Ga dry orthopyroxene-bearing granitoid magmatism in the ADMB (Fareeduddin and Kröner, 1988), Bhowmik et al. (2018) presented three possible interpretations of the $1.43 \mathrm{Ga}$ zircon date in the PilwaChinwali charnockite: (1) charnockite emplaced at ca. 1.72 Ga (age of the Sandmata Charnockite, Sarkar et al., 1989, Buick et al., 2006) was re-metamorphosed between $1.09 \mathrm{Ga}$ and $1.01 \mathrm{Ga}$ implying the
1.4 Ga date as a partially reset age; (2) it represents the timing of a Mesoproterozoic high-temperature magmatic event, hitherto unrecognized from other domains of the ADMB and (3) the $1.43 \mathrm{Ga}$ zircon represents pristine or differentially reset inherited component in the magmatic rock.

Recent studies draw correlation of the ADMB with chronologically and tectono-metamorphically similar basins in Rodinia continent assembly (for example, the Jiangnan Fold Belt in S.China, Zhao, et al., 2018) and the Proterozoic mobile belts of central, eastern and southeastern India (Bhowmik and Dasgupta, 2012). Such correlations, therefore, suggest that the ADMB constitutes a vital part of the growth and the assembly of the Greater Indian Landmass in Rodinia.

\section{The Crustal Evolutionary Models}

Ensialic Rifting Model: One of the earliest tectonic models (post geosynclinal concepts; Sharma, 1995) proposes the ensialic rifting (at ca 2000-1900 Ma) as the reason for the formation of large Aravalli basin followed by subsidence and crustal shortening (assuming Aravalli orogeny at 1900-1800 Ma). Another ensialic rifting (1800$1700 \mathrm{Ma}$ ) favored Delhi sedimentation, followed by underplating by mantle magma, decoupling of mantle-lithosphere, and subduction (ca 1800-1700 Ma). Deformation of Delhi sediments (Delhi orogeny at ca 1700-1500 Ma) and a substantial period (ca 1500-900 Ma) of mantle lithospheric welding led to the tectonic exhumation of the granulites, followed by several episodes of Erinpura type granite magmatism.

Plate-Tectonic Model: Using trace element geochemistry and petrofacies analysis Banerjee and Bhattacharya $(1989,1994)$ applied plate tectonic concepts to assign each of the Aravalli clastic rocks to specific tectonic setting and interpret the evolution of the Aravalli basin in a passive margin setting which changed to active margin tectonics towards the end phase. Sinha-Roy (2000) visualized Proterozoic development in the region involving Mewar/Bundelkhand craton and Marwar Craton towards east and west, respectively. The Aravalli basin formed during the Paleoproterozoic as an aulcogen that widened southwards from a triple junction near Nathdwara. A set of strike-slip faults from aulacogen triple point splayed and resulted in the formation of pull-apart basins (mineralized belts like RajpuraDariba, Agucha-Bhilwara, etc.). According to this author, the Aravalli aulacogen closed at $1800 \mathrm{Ma}$ (may need revision because of newly generated dates). A suture zone represented by the Antri-Rakhabdeo tectonic line was formed, and synkinematic granites (Darwal, Anjana) were emplaced when the two cratonic blocks collided, and the oceanic basin floor thrust under the continental block. Another major strikeslip fault emanating from the triple junction opened the Delhi basins in two tectonic domains: (i) the NDFB evolved as fault-bound grabens and half-grabens as part of aborted rifts were intruded by granites at 1450-1650 Ma and (ii) SDFB, a linear belt formed as a transtensional rift that opened into a sea like the Red Sea, with eastern continental platform sediments (Bhim and Rajgarh groups) and the western volcanic suites of Barotiya and Sendra Groups consisting of basaltandesite-rhyolite (island arc suite). This trough was closed by subduction, with the formation of a trench, a magmatic arc, and a marginal basin. The 1000-1100 Ma old Ranakpur gabbros and coeval Phulad ophiolite suite/mélange were emplaced and was followed by Sendra-Ambaji and Erinpura granites (900 Ma) due to westward 
thrusting of the Delhi oceanic crust. Several new publications during recent years focus the development of individual segments of the ADMB under the overall ambit of the plate-tectonic models envisaged above (see Wang et al., 2018; Zhao et al. 2018.)

The elusive Marwar Craton: An critical necessity for the understanding of the plate-tectonic models for ADMB would be the existence of an elusive cratonic segment towards west, hypothetically proposed as the Marwar Craton in Sinha Roy's aforementioned tectonic models. Pre-Aravalli gneisses identified by Heron (1953) to the west of Delhi fold belt is now found to be migmatised para-gneisses that contained detrital zircons of ages between 2258 Ma and 1695 Ma suggesting its contemporaneity to the migmatised Aravalli gneisses of the Bhilwara sector. In this context, the recent report of Eo-archean (3671 Ma) and Mesoarchean (2985 Ma) dates (Wang et al., 2018) in Alwar basin gains utmost significance as it points towards the presence of Eo- to Neo Archean cratonic blocks during the deposition of the NDFB sediments. It needs to be resolved whether this cratonic segment is (a) a part of Marwar Craton (that ideally would have existed to the west of SDFB); or (b) a part of the Greater Marwar Craton spreading from west to north-northeastern parts of SDFB or (c) it represents a totally independent cratonic block. Regional tectonic implications of the existence of a cratonic block towards the northern part of the NDFB needs to be thoroughly evaluated.

\section{Acknowledgment}

The two authors of this article are equally responsible for the views expressed therein. Banerjee expresses his gratitude to S.P. Nautiyal and Muktinath of Geological Survey of India for providing an opportunity to work in the Aravalli terrane during his short stint in GSI in 1967-1970. He also thanks Indian National Science Academy, New Delhi for grants under the Honorary Scientists Scheme and Aditi Sharma, Research Student in Delhi University, and AK Jain for help in drawing some figures. Faredduddin dedicates his contribution to Utpal Bose, of Geological Survey of India, for introducing him to the wonderful world of Rajasthan geology in the year 1983. We wish to thank two reviewers Sumit Ray and T.K. Biswal, for their thoughtful comments that helped us in reorganizing some parts of this paper. We thank Saibal Gupta for handling our paper in highly professional manner.

\section{References}

Absar, N. and Sreenivas.B., 2015. Petrology and geochemistry of greywackes of the $\sim 1.6 \mathrm{Ga}$ Middle Aravalli Supergroup, northwest India: Evidence for active margin processes. Internat. Geol. Review, v.57, 2, pp.134-158

Ahmad, T. and Tarney, J., 1994, Geochemistry and petrogenesis of late Archaean Aravalli volcanics, basement enclaves and granitoids, Rajasthan. Precambrian Res. v.65, pp.1-23.

Ahmad, I., Mondal, M.E.A. and Satyanarayanan, M., 2016, Geochemistry of Archean metasedimentary rocks of the Aravalli craton, NW India: Implications for provenance, paleoweathering and supercontinent reconstruction. J. Asian Earth Sci. v.126, pp.58-73.

Ahmad, T., Dragusanu, C., Tanaka,T., 2008. Provenance of Proterozoic Basal Aravalli mafic volcanic rocks from Rajasthan, Northwestern India: Nd isotopes evidence for enriched mantle reservoirs. Precamb Res. v.162, pp.150-159.
American Commission on Stratigraphic Nomenclature, Code of Stratigraphic Nontcnclature. 1961. Bull. Am. Ass of Petroleum Geol., v. 45,pp. 645-665.

Arora, D., Pant, N C Fareeduddin, Surbhi Sharma,Raghuram, and Mohd. Sadiq (2017) Inferring a Neoproterozoic orogeny preceding the Rodinia break-up in the Sirohi Group, NW India. In: Pant, N. C. \& Dasgupta, S. (eds) Crustal Evolution of India and Antarctica: The Supercontinent Connection. Geological Society, London, Special Publications, 457, https://doi.org/ 10.1144/SP457.8.

Ashwal, L., Solanki, A., Pandit, M., Corfu, F., Hendriks, B., Burke, K.\&Torsvik, T. 2013. Geochronology and geochemistry of Neoproterozoic Mt. Abu granitoids, NW India: Regional correlation and implications for Rodinia paleogeography. Precambrian Research, v. 236, 265-281.

Banerjee,D.M.,1971a. Aravallian stromatolites from Udaipur, Rajasthan. Jour. Geol.Soc. India, v.12,pp.349-355

Banerjee, D.M.,1971b Precambrian stromatolitic phosphorites of Udaipur, Rajasthan. Geol.Soc. America Bull.v.82, pp.2319-2330.

Banerjee, D.M. and Bhattacharya, P., 1989.Petrofacies analysis of the clastic rocks in the Proterozoic Aravalli Basin, Udaipur district, south-central Rajasthan. Indian Minerals, v.43, nos 3\&4, pp. 194225

Banerjee,D.M.and Bhattacharya, Prosun., 1994. Petrology and geochemistry of greywackes from the Aravalli Supergroup, Rajasthan, India and the tectonic evolution of a Proterozoic Sedimentary basin. Precamb. Res., v. 67, pp.11-35.

Banerjee, D.M., Schidlowski.M., and Arneth,J.D., 1986.Genesis of Upper Proterozoic-Cambrian phosphorite deposits of India: isotopic inferences from carbonate fluorapatite, carbonate, and organic carbon. Precamb.Res. v.33, pp.239-253.

Banerjee DM 1996 A Lower Proterozoic Palaeosol at BGC-Aravalli Boundary in South-Central Rajasthan, India. J Geol Soc India 48:277-288

Bhola, A.M. 1989 Petrology of regionally metamorphosed pelitic schists, SSW of Narnaul, Mahendragarh district, Haryana, India. In P.S. Saklani Ed. Metamorphism, Ophiolites and Orogenic belts. Current Trends in Geology XII, pp.85-102.

Bhowmik., S.K., Dasgupta S 2012 Tectonothermal evolution of the BGC in central Rajasthan, NW India: present status and correlation Journal of Asian Earth Sciences, v. 49, pp. 339-348

Bhowmik, S.K., H.-J. Bernhardt, S. Dasgupta 2010 Grenvillian age high pressure upper amphibolite-granulite metamorphism in the Aravalli-Delhi Mobile Belt, Northwestern India: new evidence from monazite chemical age and its implication. Precambrian Research, v.178, pp. 168-184

Bhowmik S. K., Dasgupta, S.,Baruah, S.,.S. and Kalita, D. 2018. Thermal history of a Late Mesoproterozoic paired metamorphic belt (?) during Rodinia assembly: New insight from mediumpressure granulites from the Aravalli-Delhi Mobile Belt, Northwestern India. Geoscience Frontiers v. 9, pp 335-354

Biju-Sekhar, S., Yokoyama, K., Pandit, M., Okudaira, T., Yoshida, M. and Santosh, M., 2003, Late Paleoproterozoic magmatism in Delhi Fold Belt, NW India, and its implication: evidence from EPMA chemical ages of zircons. J. Asian Earth Sci. v.22, pp.189207.

Biswal, T. K 1988, Polyphase deformation in Delhi rocks, southeast of Amirgad, Banaskantha, Dist Gujarat.Mem. Geol.Soc. India, v. 7., pp.267-278

Biswal, T.K., Gyani, K.C., Parthasarathy, R., D.R. Pant 1998, Implications of the geochemistry of the pelitic granulites of the Delhi supergroup, Aravalli Mountain Belt, Northwestern India Precambrian Research, 87 , pp. 75-85

Bose, S. Seth, P. Dasgupta N 2017, Meso-Neoproterozoic mid-crustal 
metamorphic record from the Ajmer-Shrinagar section, Rajasthan, India and its implication to assembly of the Greater Indian landmass during the Grenvillian-age orogenesis. In: N.C. Pant, S. Dasgupta (Eds.), Crustal Evolution of India and Antarctica: The Supercontinent Connection, v. 457, Geological Society, London, Special Publications,

Bose, U 1989, Correlation problems of the Proterozoic stratigraphy. Ind, Min. v. 43, pp.183-193.

Buick I.S., C. Allen, M. Pandit, D. Rubatto, J. Herman 2006The Proterozoic magmatic and metamorphic history of the BGC, central Rajasthan, India: LA-ICP-MS U-Pb zircon constraints Precamb. Res.,v. 151, pp. 119-142

Chattopadhyay, N., Mukhopadhyay, D. P. Sengupta 2012, Reactivation of basement: example from the Anasagar granite gneiss complex, Rajasthan, Western India. R. Mazumder, D. Saha (Eds.), Proterozoic of India, Geological Society London Special Publication. v 365, pp. 219-245

Choudhary, A., Gopalan, K. and Sastry, C.A., 1984, Present status of the geochronology of the Precambrian rocks of Rajasthan. Tectonophysics, v.105, pp.131-140.

Code of Stratigraphic Nomenclature of India 1971, Geological Survey of India Misc Publ. v. 20, p. 43

Coulson, A.L.,1933. The geology of the Sirohi State, Rajputana, Mem.Geol.Surv India, v.63, 166pp

Crawford, A., 1970, The Precambrian geochronology of Rajasthan and Bundelkhand, northern India. Can. Jour. Earth Sci., v.7, pp.91-110.

Crawford, A.R., 1975. Rb-Sr age determination for the Mount Abu Granite and related rocks of Gujarat. Journal of Geological Society of India. V. 16, 20-28.

Crookshank, H.1948, Minerals of the Rajputana Pegmatites in Trans. Min. Geol. Met. Inst., India, v. 42,pp.105-189.

Dasgupta, S., Guha, D., Sengupta, P., Miura, H. and Ehl, J., 1997, Pressure-temperature-fluid evolutionary history of the polymetamorphic Sandmata granulite complex, Northwestern India. Precambrian Res., v.83, pp.267-290

Deb, M. and Thorpe, R., 2004, Geochronological constraints in the Precambrian geology of Rajasthan and their metallogenic implications: sediment-hosted Lead-Zinc Sulphide Deposit. Narosa Publ. House New Delhi, pp. 246-263.

Deb, M. and Sehgal, U. 1997 Petrology, geothermobarometry and C$\mathrm{O}-\mathrm{H}-\mathrm{S}$ fluid compositions in the environs of Rampura-Agucha $\mathrm{Zn}-(\mathrm{Pb})$ ore deposits, Bhilwara District, Rajasthan. Proc. Indian Acad. Sci (Earth Planet. Sci), v.106, pp.343-356.

Deb, M., Thorpe,R.I., Cumming,G.L. and Wagner,P.A. 1989. Age, Source, and Stratigraphic Implications of $\mathrm{Pb}$ Isotope Data for Conformable, Sediment-hosted, Base Metal Deposits in the Proterozoic Aravalli-Delhi Orogenic Belt, Northwestern India. Precamb.Res., v.43, pp.1-22

Deb, M.,Thorpe, R.I., Kristic, D.,Corfu,F. Davis,D.W.2001. Zircon $\mathrm{U}-\mathrm{Pb}$ and galena $\mathrm{Pb}$-isotope evidence for an approximate $1.0 \mathrm{Ga}$ terrane constituting the western margin of the Aravalli-Delhi orogenic belt, northwestern India. Precambrian Research, v.108, pp.195-213

Desai, S.J., Patel, M.P, and Merh, S.S 1978 Polymetamorphites of Balaram-Abu Road area, North Gujarat and Southwest Rajasthan. Jour. Geol. Soc. India., v.19, pp. 383-394.

deWall, H. Pandit, M.K. and Chauhan, N.K.,2012. Palaosol occurrences along the Archean-Proterozoic contact in the Aravalli craton,NW India. Precamb Res.,v.216, pp120-131.

Dharma Rao, C.V., Santosh, M., Purohit, R., Wang, J., Jiang, X. and Kusky, T., 2011, LA-ICP-MS U-Pb zircon age constraints on the Paleoproterozoic and Neoarchean history of the Sandmata Complex in Rajasthan within the NW Indian Plate. Journal of
Asian Earth Sciences, v.42, pp.286-305

Dutta, M.K.,1980, Petrology of rocks around Jhamarkotra and its bearing on environment of phosphorite formation. Unpublished M.Sc Dissertation, University of Delhi, 51 p.

Easton R. M 2009, A guide to the application of lithostratigraphic terminology in Precambrian terrains. Stratigraphy, v. 6, no. 2, pp. 117-134

Fareeduddin 1995, Field setting, petrochemistry, and P-T Regime of the Deep Crustal Rocks to the northwest of the Aravalli-Delhi Mobile Belt, North-Central Rajasthan. Mem. Geol. Soc. India, v. 31,pp.117-139.

Fareeduddin, A. Kröner 1998 Single zircon age constraints on the evolution of Rajasthan granulites B.S. Paliwal (Ed.), Precambrian Rocks of India, pp. 547-556

Fareeduddin, M.A. Shankar, B. Basavalingu, A.S. Janardhan 1994 P$\mathrm{T}$ conditions of pelitic granulites and associated charnockites of Chinwali area, west of Delhi fold belt, Rajasthan Journal Geological Society of India, v. 43, pp. 169-178

Fareeduddin, Reddy, M.S and Bose, U. 1995 Reappraisal of Delhi Stratigraphy in the Ajmer-Sambhar Sector, north-central Rajasthan. Jour. Geol. Soc. India, v. 45, pp. 667-679.

Fareeduddin, B.R. Venkatesh, R. Hanumantha, P.R. Golani, B.B. Sharma, and S. Neogi 2014, Petrology and stable isotope (S,C,O) studies of selected sediment-hosted base metal ore deposits in Proterozoic Aravalli-Delhi Fold Belts, Rajasthan. Jour Geol. Soc. India. v. 83, pp.119-141.

Gandhi, S. M., Paliwal, H.V. and Bhatnagar, S.N. 1984 Geology and ore reserve estimates of Rampura-Agucha lead-zinc deposit, Bhilwara District. Jour. Geol. Soc. India, v.25, pp.689-705.

Gopalan, K, and Choudhury,A.K 1984 The crustal records in Rajasthan. Proc. Indian Acad. Sci., v. 93,pp. 337-342

Gopalan, K., Macdougall, J., Roy, A. and Murali, A., 1990, Sm-Nd evidence for $3.3 \mathrm{Ga}$ old rocks in Rajasthan, northwestern India. Precambrian Res., v. 48, pp.287-297.

Gouda, H.C., Fareeduddin, et al., 2015. Aeromagnetic anomaly maps of Aravalli Craton and their interpretations: some new insights on stratigraphy and metallogeny of the region. In: GSI (2011) Geology and Mineral Resources of Rajasthan. Misc. Pub. No. 30., ${ }^{\text {rd }}$ Revised Edition, 130p.

Guha, D. B. \& Bhattacharya, A. K. 1995, Metamorphic evolution and high-grade reworking of the Sandmata Complex granulites. In: Gupta, K. R. \& Sinha-Roy, S. (eds) Continental Crust of Northwestern and Central India. Memoirs of the Geological Society of India 31, 163 -198.

Gupta, B.C., 1934, The geology of central Mewar. Geol. Surv. India Mem. v.65, pp.107-169.

Gupta, P. and Bose U 2000, An update onGeology of the Delhi Supergroup in Rajasthan. Geol. Surv. India, Sp. Pub. No. 55, pp. 287-366.

Gupta P., Fareeduddin, Reddy, M.S and Mukhopadhyay 1995,Straigraphy and structure of Delhi Supergroup of rocks in central part of Aravalli Range. Rec.Geol.Sur of India,V.120, pp.1226.

Gupta, P., Guha, D.B. and Chattopadhyay, B., 1998. Basement-cover relationship in the Khetri Copper Belt and the emplacement mechanism of the granite massifs, Rajasthan, India; Jou. Geol. Soc. Ind. V.52, pp. 417-432

Gupta, S.N., Arora, Y.K., Mathur, R.K., Iqbaluddin; Prasad B., Sahai,T.N., Sharma,S.B., 1997. Precambrian geology of the Aravalli region, southern Rajasthan, and northeastern Gujarat. Mem.Geol.Survey of India, 262p.

Hacket, C. A. 1877, Note on Aravalli series in northeastern Rajputana. Rec.Geol.Surv. India, v. 10 (2), pp. 84-92.

Hazarika, P., Upadhyay, D., B. Mishra (2013) Contrasting 
geochronological evolution of the Rajpura-Dariba and RampuraAgucha metamorphosed Zn-Pb deposit, Aravalli-Delhi belt, India Journal of Asian Earth Sciences, 73, pp. 329-339

Heron, A.M. 1917 Geology of northeastern Rajputana and adjacent districts.Mem. Geol. Surv.India, v. 45, 128p.

Heron, A.M., 1953, The Geology of central Rajputana. Mem. Geol. Surv. India, v.79. 389p.

ISSC (International Subcommission on Stratigraphic Classification) of IUGS International Commission on Stratigraphy, 1994, International stratigraphic guide (2d edition, Amos Salvador, ed.): Trondheim, Norway, International Union of Geological Sciences, and Boulder, Colorado, Geological Society of America, 214 p.

Just, J., Schulz, B., de Wall, H., F. Jourdan, Pandit M.K. 2011, Monazite CHIME/EPMA dating of the Erinpura granitoid deformation: implications for Neoproterozoic tectonothermal evolution of NW India Gondwana Research, v. 19, pp. 402-412.

Kaur, P., Zhe Armin and Choudhuri, Navin 2016, Unraveling the record of Archaean crustal evolution of the Bundelkhand Craton, northern India using U-Pb zircon-monazite ages, Lu-Hf isotope systematics, and whole-rock geochemistry of granitoids, Precamb. Res. 281, DOI: 10.1016/j.precamres.2016.06.005

Kaur, P., Naveen Choudhury and Nusrat Elyas 2018, Origin of trondhjemite and albitite at the expanse of A-type granite, Aravalli Orogen, India: Evidence for new metasomatic replacement fronts. Geoscience Frontiers. http://doi.org/10.1016/j.gsf.2018.09.019

Kaur, P, Armin Zeh, Naveen Chaudhri 2019, Archean crustal evolution of the Aravalli Banded Gneissic Complex, NW India: Constraints from zircon U-Pb ages, Lu-Hf isotope systematics, and wholerock geochemistry of granitoids. Precamb. Res., V. 327, pp. 81102

Khan, M.S. Smith, T. E., Raza, M and Huang, J 2005, Geology, Geochemistry and tectonic significance of mafic-ultramafic rocks of Mesoproterozoic Phulad Ophiolite Suite of South Delhi Fold Belt, NW Indian Shield. Gond. Res., v. 8, pp.553-566.

Kundu A., Kazim Kamal and Sharma S.2004, Metamorphism in North Delhi Fold Belt - A case study from Southwest Haryana and Adjacent Parts of Rajasthan. Indian Minerals, v.58, pp.17-26.

Kumpulainen (Ed.) 2017 Guide for geological nomenclature in Sweden, GFF, 139:1, 3-20, DOI: 10.1080/11035897.2016. 1178666. To link to this article: https://doi.org/10.1080/ 11035897.2016.1178666

Lal, R.K. and Shukla, R.S. 1975, Genesis of cordierite - gedrite cummingtonite rocks of the northern portion of the Khetri copper belt, Rajasthan, India. Lithos, v.5, pp.175-186.

Malhotra, G, and Pandit, M.K 2000, Geology and mineralization of Jahazpur belt, southeastern Rajasthan. In: M. Deb (Ed) Crustal Evolution and Metallogeny in Northwestern Indian Shield, Narosa Publ. House, New Delhi,pp.115-125.

MacDougal, J.D., Gopalan, K., Lugmair, G.W and Roy, A.B 1983, The Banded GneissicComplex of India: Early crust from the depleted mantle at 3.5 AE. Trans.Amer Geophys. Union, v. 64, p.381

Mehdi, M., Santosh Kumar and Naresh C. Pant 2015, Low-Grade Metamorphism in the Lalsot-Bayana Sub-basin of the North Delhi Fold Belt and its Tectonic Implication. Jour. Geol. Soc. of India, v.85, pp.397-410.

McKenzie, N.R., Hughes,N.C., Myrow, P.M., Banerjee,D.M., Deb, M.,and Planavasky, N.J.,2013. New Age constraints for the Proterozoic Aravalli-Delhi successions of India and their implications, Precamb. Res., v.238, pp.12-28.

Melezhik, V.A.,Huhma,H.,Condon D.J., Fallick,A.E. and Whitehouse, M.J.,2007.Temporal constraints on the Paleoproterozoic Lomagundi-Jatuli carbon isotopic event. Geology, v.35, pp.655658
Melezhik, V.A., Purohit, R., and Papineau,D.,2014. Comments on "New age constraints for the Proterozoic Aravalli-Delhi successions and their implications,” Precam. Res.., v.246, pp.319320

Mishra, B., Upadhyay, D. and Bernhardt, Heinz-Juergen 2006, Metamorphism of the host and associated rocks at the RajpuraDariba massive sulphide deposit, Northwestern India. Jour. Asian Earth Sci., v.26, pp.21-37.

Mishra D.C and Ravi Kumar M 2014, Proterozoic orogenic belts and rifting of Indian cratons: Geophysical constraints. Geoscience Frontiers v.5 25-41.

Mondal, M.E.A. and Raza, A., 2013, Geochemistry of sanukitoid series granitoids from the Neoarchaen Berach granitoid batholiths, Aravalli craton, northwestern Indian shield: Curr. Sci., v.105, pp.102-108.

Mukhopadhyay, D., 2000. Anasagar Gneiss: A folded Granitoid in the Proterozoic South Delhi Fold Belt, central Rajasthan; Proc. Ind. Acad. Sci., (Earth Planet. Sci.), 109, pp. 21-37.

Murphy, Michael A. and Amos Salvador, 1999, International Subcommission on Stratigraphic Classification of IUGS International Commission on Stratigraphy International Stratigraphic Guide - An abridged version, Episodes v. 22,No. 4, pp.255-272

NACSN (North American Commission on Stratigraphic Nomenclature), 1981, Draft North American stratigraphic code: Canadian Society of Petroleum Geologists, 63 p

Naha, K., and Halyburton,R.V.,1974. Early Precambrian stratigraphy of central and southern Rajasthan, India. Precamb.Res, v.1,pp.5573.

Naha, K and Mohanty SP 1988, Response Of Basement And Cover Rocks To Multiple Deformations: A Study From The Precambrian Of Rajasthan, Western India Precambrian Research, 42 (1988) 77-96.

Naha, K and Mohanty, S 1990, Structural studies in the Pre-Vindhyan rocks of Rajasthan. A summary of work of the last three decades. Proc. Indian Acad.Sci.,v.99,pp. 279-290.

Naha, K., Mukhopadhyay, D.K., Mohanty,R., Mitra, S.K. and Biswal T.K.,1984. Significance of contrast in the early stages of the structural history of the Delhi and the pre-Delhi rock group in the Proterozoic of Rajasthan, western India. Tectonophysics, v.105, pp193-206.

Naha, K., Mukhopadhyay and Mohanty, R 1988 Structural evolution of the rocks of the Delhi Group around Khetri, northeastern Rajasthan.Mem. 7, Geol. Soc. India, pp.207-246.

North American Commission on Stratigraphic Nomenclature (2005) North AmericanStratigraphic Code. AAPG Bulletin, v. 89, no. 11, pp. 1547-1591

Pandey, Mayuri., Naresh C. Pant, Santosh Kumar 2013, Criteria to distinguish between regional and contact zone monazite - a case study from Proterozoic North Delhi Fold Belt (NDFB), India. Episodes, v. 36, pp. 275-289.

Pandit, M.K., Carter, L.M., Ashwal, L.D., Tucker, R.D., Torsvik, T.H., Jamtveit, B., Bhushan, S.K., 2003. Age, petrogenesis and significance of $1 \mathrm{Ga}$ granitoids and related rocks from the Sendra area, Aravalli Craton, NW India. Journal of Asian Earth Sciences v. 22, 363-381.

Pandit, M.K., de Wall, H. G and Chauhan, N.K 2008, Paleosol at the Archean-Proterozoic contact in NW India, revisited - Evidence for oxidizing conditions during paleo-weathering ?, J. Earth Syst. Sci. 117, No. 3, pp. 1-9.

Pant, N.C., Prasad, Sheo and Kundu, A. 2000 Subcalcic amphibole bearing rocks from Mahendragarh district, Haryana-Implication on metamorphism of the Delhi Fold Belt. In: M.Deb (Ed.), Crustal Evolution and Metallogeny in the Northwestern Indian Shield. 
Narosa Publishing House, NewDelhi, pp.138-157.

Pant, N.C., Kundu, A. and Joshi, S. 2008 Age of metamorphism of Delhi Supergroup rock selection microprobe ages from Mahendragarh district, Haryana. Jour. Geol. Soc. India, v.72, pp.365-372.

Pascoe, E .H., 1950. A manual of geology of India and Burma. Geol. Surv. Ind. Miscellaneous Publication. v. 1 : 245-250.

Papineau,D., Purohit, R., Goldgerg,T., Pi,D., Shields,D.A., Bhu, H., Steele,A.,and Fogel, M.L.,2009. High primary productivity and nitrogen cycling after the Paleoproterozoic phosphogenic event in the Aravalli Supergroup, India.,Precamb. Res. v.171, pp.3756.

Poddar, B.C. and Mathur,R.K.,1967. A note on the repetitious sequence of greywacke-slate-phyllite in the Aravalli system around Udaipur, Rajasthan, Bulletin Geol.Soc India, v.2, pp.83-87

Purohit,Bhu,H., Mehta,P., and Avadich,P.C.,2012. Tectonostratigraphic status of the Proterozoic Babarmal Pink Marble from the Aravalli Supergroup, Jour.Geol.Soc.India, v.79, pp.235-250.

Purohit, R., Bhu H.,Sarkar A.,and Ram,J.,2015. Evolution of the ultramafic rocks of the Rakhabdeev and Jharol Belts in southeastern Rajasthan, India: New evidence from the imagery mapping.petro-mineralogical and $\mathrm{OH}$ stable isotope studies: Jour Geol.Soc. India, v.85, pp331-338.

Raja Rao, C.S., Poddar,B.C., Basu, K.K. and Dutta A.,1971. Precambrian stratigraphy of Rajasthan-A review. Rec.Geol.Surv India, v.101, pp.60-79

Ray,S.K 1974, Structural history of theSaladipura pyrite-pyrrhotite deposit and associated rocks, Khetri Copper Belt,Rajasthan. Jour.Geol.Soc.India, v.15, pp.227-246.

Ray, S.K. 1988. Structural controls of copper mineralization near Bajta, Ajmer Dist., Rajasthan., Geol Soc.India, Mem. 7, pp.363372

Ray, S. K. 1990. The albitite tine of northern Rajasthan- A fossil intra-continental rift zone. Journal Geological Society of India, v. 86 , no. 4, pp. 413-423

Raza, M. and Khan, M.S., 1993. Basal Aravalli volcanism: Evidence for an abortive attempt to form Proterozoic ensialic greenstone belt in northwestern part of Indian Shield. J. Geol. Soc. Ind. v.42, pp. 493-512.

Roy,A.B. and Paliwal, B.S. 198,1 Evolution of Lower Proterozoic epicontinental deposits: stromatolite bearing Aravalli rocks of Udaipur, Rajasthan, India, Precamb Res.v.41 pp.49-74u.

Roy, A. B 1988, Stratigraphic and tectonic framework of the Aravalli mountain range.Mem. No. 7., Geol.Soc.India, pp.3-32

Roy, A.B., and Kröner, A., 1996, Single zircon evaporation ages constraining the growth of the Archaean Aravalli craton, northwestern Indian shield: Geological Magazine, v. 133, p. 333342.

Roy A.B. and Jakhar S.R., 2002. Geology of Rajasthan: Precambrian to Recent; Scientific Publisher, Jodhpur, India,421 p.

Roy, A.B., Paliwal,B.S., Shekhawat S.S., Nagori D.K., GolaniP.R. and Bejarniya,B.R.,1988. Stratigraphy of the Aravalli Supergroup in the type area. Geol.Soc India Mem., v.7, p.121-131.

Roy, A.B., Kröner, A. and Laul, V. 2001 Detrital zircons, constraining basement age in a late Archaean greenstone belt of south-eastern Rajasthan, India. Curr. Sci., v.81, pp.407-410.

Roy, A.B., Kröner, A., Bhattacharya, P.K., Rathore, S., 2005. Metamorphic evolution and zircon geochronology of early Proterozoic granulites in the Aravalli Mountains of northwestern India. Geological Magazine 142, 287-302.

Roy, A.B., Kroner,A., Rathor,S., Laul, v., Purohit, R (2012) Tectonometamorphic studies from Sandmata Complex northwest Indian shield: implications on exhumation of late Proterozoic granulites in an late-Archean-Early Paleoprotrozoic granite-gneiss terrane. J. Geol.Soc. India, v.79., pp. 323-334.

Roy-Choudhury, M.K and Dasgupta, S.P. 1964. On the geology and mineralization in the Khetri copper belt,Jhunjunu and Sikar Districts, Rajasthan. Ind.Minerals, v. 31, pp.188-198

Russell, Jonathan, 1993. Pb-Pb dating of Precambrian Carbonate Rocks, Unpublished Ph.D. thesis, University of Oxford, England. $256 \mathrm{p}$.

Sarangi S, Srinivas B, Das Sharma S, Gopalan K and Roy AB (2006). $\mathrm{Pb}-\mathrm{Pb}$ age of Jhamarakotra Formation: constraints on the Age of Aravalli Supergroup, Rajasthan. J. Geol Soc. of India, v.67, pp.442-446

Sarkar, G. Ray Barman, T. . Corfu F., 1989. Timing of continental arc magmatism in northwest India: evidence from $\mathrm{U}-\mathrm{Pb}$ zircon geochronology, Journal of Geology, v. 97 , pp. 607-612

Saha, L., Bhowmik, S.K., Fukouka, M and Dasgupta M (2008) Contrasting episodes of regional granulite facies metamorphism in enclaves and host gneisses fom the ADMB, Northwest India,Jour. Pet. v. 49, pp. 107-128.

Schidlowski,M., Eichmann,R.,Junge,C.E.,1976. Carbon isotope geochemistry of the Precambrian Lomagundi carbonate province, Rhodesia, Geochim. Cosmochim. Acta, v. 40, pp449-455.

Sen, S.,1980. Precambrian stratigraphic sequence in a part of the Aravalli Range, Rajasthan: a re-evaluation. Quart. Jour. Geol. Min. Metal Soc. India. v. 52, No. 2, pp. 67-76.

Sharma, R.S., 1988. Patterns of metamorphism in the Precambrian rocks of the Aravalli Mountain Belt. Mem. Geol. Soc. India, v. 7, pp. 33-75.

Sharma, R. S., 1995 : An evolutionary model for the Precambrian crust of Rajasthan : Some petrological and geochronological considerations. In: Continental crust of Northwestern and Central India, (Eds : S. Sinha Roy and K.R. Gupta), Mem. Geol. Soc. Ind., 3 1, pp.9 1 - 116 .

Sharma, R.S. and Mondal, M., 2018, Evolution of the Indian Shield: A New Approach, In: Geological Evolution of the Precambrian Indian Shield. Springer, pp. 17-38.

Sharma, R.S., Sills, J.D., Joshi, M., 1987, Mineralogy and metamorphic history of norite dykes within granulite facies gneisses from Sand Mata, Rajasthan, NW India. Miner. Mag. v. 51, pp.207-215.

Shekhawat, L.S., Pandit, M.K., Joshi, D.W., 2007. Geology and geochemistry of Paleoproterozoic low-grade metabasic volcanic rocks from Salumber area, Aravalli Supergroup. NW India. J. Earth Syst. Sci. 116, 511-524.

Singh,S.P.,1988. Stratigraphy and sedimentation pattern in the Proterozoic Delhi Supergroup, Northwestern India.Mem.Geol. Soc. India, v.7,pp.193-206.

Singh, Y.K., Waele, B.D. ,S. Karmakar, S. Sarkar, Biswal T.K .,2010. Tectonic setting of the Balaram-Kui-Surpagla-Kengora granulites of the south Delhi terrane of the Aravalli mobile belt, NW India and its implication on correlation with the east African Orogen in the Gondwana assembly Precamb.Res., v.183 , pp. 669-688

Sinha-Roy, S., 1984: Precambrian crustal interactions in Rajasthan, NW India.In: Crustal evolution or the Indian shield and its bearing on Metallogeny. Ind. Jour. Earth Sci. Seminar \-bl., pp. 84-9 1.

Sinha Roy,S., 1988 Proterozoic Wilson Cycles in Rajasthan, NW India. Mem. Geol. Soc. India, v. 7, pp.95-107.

Sinha-Roy,S., 2000. Precambrian terrain evolution in Rajasthan. Geol. Surv. India. Spec. Publ. No. 55., pp. 275-286

Sinha-Roy S., Mohanty,M. and Guha,D.B., 1993. Banas dislocation zone in Nathdwara-Khamor Area, Udaipur district, Rajasthan, and its significance on the basement cover relations in the Aravalli Fold Belt. Curr.Sci. v.65, no.1, pp.68-72.

Sinha Roy S., Malhotra,G. and Mohanty,M., 1998. Geology of Rajasthan, Geol.Soc.India, 278 p. 
Sreenivas, B., Sharma,S.D., Kumar, B., Patil,D.J.,Roy, A.B. and Srinivasan,R., 2001. Positive $\delta^{13}$ Cexcursion in carbonate and organic fractions from the Paleoproterozoic Aravalli Supergroup, northwestern India. Precamb. Res., v.106, no.3-4, pp.277-290.

Srikarni, C. Limaye, M. . Janardhan A.S.,2004. Sapphirine-bearing granulites from Abu-Balarm area, Gujarat state: Implications for India-Madagascar connection. Gondwana Research, v.7, pp. 1214-1218

Vinogradov, A., Tugarinov, A., Zhykov, C., Stapphikova, N., Bibikova, E., and K. Khorre 1964. Geochronology of Indian Precambrian, Int. Geol. Congo Rep. 22nd. Session, Pt. X, p.553-567.

Tiwari, S.K and Biswal,T.K (2019) Dynamics, EPMA Th U Total Pb Monazite Geochronology and Tectonic Implications of Deformational Fabric in the Lower Middle Crustal Rocks: A Case Study of Ambaji Granulite, NW India.Tectonics. https://doi.org/ 10.1029/2017TC004891

Tobisch, O.T. Collerson, K.D., Bhattacharya, T, Mukhopadhyay, D.,1994. Structural relationship and Sr-Nd isotope systemstics of polymetamorphic granitic gneisses and granitic rocks from central Rajasthan, India - implications for the evolution of the Aravalli craton. Precamb. Res.,v. 65 , pp. 319-339.

Upadhyaya, R., Sharma B.L. Jr., Sharma,B.L andRoy,A.B 1992, Remnants of greenstone sequence from the Archean rocks ofRajasthan. Curr.Sci., vo. 63., No.2., pp.87-92.

Volpe, A.M. . Macdougall. J D.,1990.Geochemistry and isotopic characteristics of mafic (Phulad ophiolite) and related rocks in

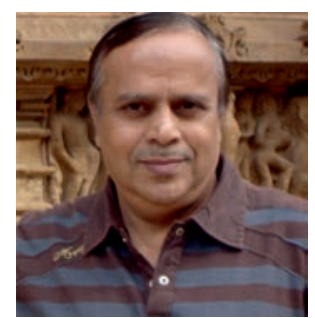

Dr. Fareeduddin, Chair Legacy Committee, $36^{\text {th }}$ International Geological Congress and Consultant Geologist, Bangalore Metro Rail Corporation has served earlier at Geological Survey of India, Geological Society of India and in IUGS (as Editor Episodes). His fields of specialization include Precambrian terrains, mineral exploration, geochemistry, petrology, heritage stones and engineering geology. He has published over 80 research papers in peer reviewed journals, authored and edited two books each and has convened scientific meetings including the $10^{\text {th }}$ International Kimberlite Conference. He is the recipient of National Mineral Award (1994), B.P. Radhakrishna Prize (2007) and S. Narayanswamy Award (2010). the Delhi Supergroup, Rajasthan, India: implications for rifting in the proterozoic. Precamb. Res.,v. 48, pp. 167-191

van Lente, B., Ashwal, L.D., Pandit, M.K., Bowring, S.A., Torsvik, T.H., 2009. Neoproterozoic hydrothermally altered basaltic rocks from Rajasthan, northwest India: implications for late Precambrian tectonic evolution of the Aravalli Craton. Precamb. Res.,v.170, pp.202-222.

Wang,W., Cawood,P.,Pandit, M., Zhou,Mei-Fu, 2018. Evolving passive and active margin tectonics of the Paleoproterozoic Aravalli basin, NW India. Geol.Soc. America Bull. DOI:10:1130/ B35027.1.4520573/b35027.pdf

Wang, Wei, Peter A. Cawood, Manoj K. Pandit,Mei-Fu Zhou \&WeiTerry Chen 2017 Zircon U-Pb age and Hf isotope evidence for an Eoarchaean crustal remnant and episodic crustal reworking in response to supercontinent cycles in NW India. Geological Society of London, https://doi.org/10.1144/jgs2016-080

Wiedenbeck, M. \& Goswami, J. N. 1994, An ion-probe single zircon $207 \mathrm{~Pb} / 206 \mathrm{~Pb}$ age from the Mewar Gneiss at Jhamarkotra, Rajasthan. Geochimica et Cosmochimica Acta 58, 2135-2141.

Wiedenbeck, M., Goswami, J. N. \& Roy, A. B. 1996, Stabilisation of the Aravalli craton of the north-western India at 2_5 Ga: An ionmicroprobe zircon study. Chemical Geology 129, 325-340.

Zhao, Jun-Hong., Pandit, Manoj K Wei Wang, Xiao-Ping Xia, 2018. Neoproterozoic tectonothermal evolution of NW India: Evidence from geochemistry and geochronology of granitoids. Lithos, $\mathrm{v}$ 316-317 pp. 330-347.

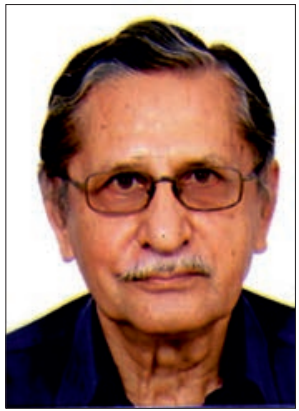

Dhiraj Mohan Banerjee obtained his Ph.D. Degree in 1967 from the University of Lucknow. Served the Geological Survey of India for two years. Joined the University of Delhi in 1970. Retired as HOD and Professor in 2007. Awarded INSA Senior Scientist/ Honorary Scientist positions. He received British Council YSS award, Alexander von Humboldt Fellowship, INSAJSPS Fellowship, National Mineral Award,Visiting Professorship in the European Institutes, Leadership in various IGCP-IUGS-IGC programs. He is a Fellow of the Indian National Science Academy, New Delhi. 